\title{
TRANSMISI DAMPAK MELALUI JARINGAN PERDAGANGAN: PENDEKATAN ASIAN-IO
}

\author{
Ibrahim \\ Tri Winarno \\ Melva Viva \\ Yanfitri
}

\begin{abstract}
Global financial crisis which began in the US in the latter part of 2008 hit a lot of countries in both trade and finance. In trade aspect, the crisis spread widely; in Indonesia, the total export value in 2009 dropped to 14,3\%. Therefore, the economy of China, tightly linked with Asian countries including Indonesia, which rapidly rose before the crisis but slowed after it should be monitored as this condition, could indirectly hold down Indonesia's GDP. Applying RAS method to update Asian IO data, this research has attempted to describe the trade structure of Asian countries in 2010. Also, it implemented a simulation of the impact of US and China's GDP decline and US exports on Indonesia's GDP, both at aggregate and sector levels. The result of the mapping shows that Indonesia is getting more dependent on China. Generally, the link between Indonesia's exported products and global production chain is weak. Indonesia's export commodities which are mostly of intermediate goods have low contribution towards value added. Moreover, the result of the simulation shows that $1 \%$ decrease in China's GDP has greater impact on Indonesia's GDP (0,14\%) than that of the US (0,05\%) and EU (0,07\%) though with similar point.
\end{abstract}

Keyword: Trade Interactions, Input Output Model

\author{
JEL Classification: F16, R15
}

1 Researcher on Economiç Research Group, Department of Ecomomic Research and Monetary Policy, Bank Indonesia.The views on this paper is solely of the authors and not necessarily reflect the views of Bank Indonesia. E-mail: ibrahim@bi.go.id, t_winarno@ bi.go.id, melva_vg@bi.go.id, yanfitri@bi.go.id 


\section{PENDAHULUAN}

Perkembangan ekonomi dunia antar negara semakin terkait erat. Keterkaitan antar negara terutama disebabkan oleh transaksi antar negara yang melibatkan pasar barang dan pasar uang sehingga menciptakan saling ketergantungan antar negara yang semakin besar. Siklus ekonomi suatu negara yang berpengaruh besar dalam perdagangan dunia akan menyebabkan pengaruh kepada negara lain, khususnya partner bisnis utama. Mekanisme transmisi siklus ekonomi suatu negara ke negara lain, dapat di jelaskan melalui jalur perdagangan barang dan jalur keuangan. Gejolak ekonomi yang terjadi di negara maju, dalam tahap awal ditransmisikan melalui pasar finansial dengan cepat, dan dalam tahap berikutnya ditransmisikan melalui jalur perdagangan secara lebih kuat dan dapat berlangsung lama. Dalam tahap berikutnya, krisis bisa berkepanjangan ketika dampak yang ditransmisikan mulai menyebar dalam kawasan yang sama, dan ketika dampak tersebut berbalik kembali ke negara maju.

Pelemahan pertumbuhan ekonomi dunia akhir-akhir ini dipicu oleh negara maju. Krisis keuangan di Amerika tahun 2008 yang belum sepenuhnya pulih, disusul oleh krisis utang di kawasan Euro, serta bencana alam di Jepang tahun 2011. Laju pertumbuhan ekonomi dunia sempat menunjukkan perbaikan di tahun 2010. Meski masih dalam level yang cukup tinggi, gejala perlambatan ekonomi juga di tunjukkan di kawasan negara berkembang. Negara berkembang Asia dengan China sebagai motor penggerak ekonomi masih menunjukkan kinerja yang relatif baik dibandingkan kawasan lain di dunia.

Sejalan dengan perlambatan ekonomi dunia, volume perdagangan dunia dan harga komoditas juga menunjukkan pelemahan di 2011. Perkembangan tersebut secara langsung, tentu berdampak bagi negara partner dagang atau negara yang pertumbuhan ekonominya bergantung pada permintaan eksternal. Dampak tidak langsung selain bersumber dari spill over pelemahan dari negara lain, dalam tahap selanjutnya dapat berdampak pada perlambatan permintaan domestik suatu negara.

Sebagai negara dengan sistem ekonomi terbuka, Indonesia juga mengalami dampak langsung maupun tidak langsung dari pelemahan yang terjadi di negara lain. Pentingnya mengetahui peta ekonomi Indonesia sebagai satu rangkaian keterkaitan ekonomi dunia, akan menjadikan dasar bagi penyusunan kebijakan yang lebih baik dan lengkap. Salah satu alat analisis yang bisa digunakan dengan baik untuk menjelaskan keterkaitan antar sektor dan antar negara, melalui jalur perdagangan adalah dengan tabel Asian IO. Dengan tabel Asian IO, simulasi dampak langsung maupun tidak langsung sebagai akibat perlambatan negara partner dagang Indonesia dapat di evaluasi.

Penelitian ini diharapkan menjadi salah satu pelengkap studi maupun analisis dampak eksternal yang telah ada sebelumnya.Tujuan dari penelitian ini adalah menganalisa struktur produksi Indonesia, mengukur dampak langsung penurunan pertumbuhan Amerika Serikat, EU, China terhadap PDB Indonesia, dan mengukur dampak tidak langsung penurunan pertumbuhan Amerika Serikat, EU, dan China terhadap output di Indonesia. 
Penelitian ini memiliki ruang lingkup dan keterbatasan atara lain analisa tabel Input Output yang digunakan merupakan pendekatan yang berbasis data statis berdasarkan karakteristik input output negara pada suatu titik tertentu, sehingga tidak dapat digunakan untuk melakukan proyeksi di masa yang akan datang. Selain itu, penggunaan metode RAS mengasumsikan bahwa tidak ada perubahan unobserved variables lainnya antara tahun 2000 sampai dengan 2010.

Bagian selanjutnya dari paper ini mengulas landasan teori dari model Input Output. Bagian tiga menjelaskan data dan metodologi yang digunakan, sementara bagian empat menguraikan hasil perhitungan dan analisisnya. Bagian kelima menyajikan kesimpulan dan menjadi penutup dari paper ini.

\section{TEORI}

Analisa Input Output pada dasarnya merupakan teori produksi dengan fungsi produksi tertentu. Hubungan inti dalam kerangka analisis ini adalah teknologi, dimana sejumlah input dan output, terlibat dalam suatu proses produksi. Optimisasi dari sisi penawaran tidak ada mengingat analisis Input Output ini mengasumsikan hubungan yang proporsional antara input dan output. Pada sisi lain, optimisasi dari sisi permintaan juga tidak ada karena untuk setiap input tenaga kerja tertentu, berkesesuaian dengan sejumlah barang konsumsi yang juga menjadi input dalam proses produksi. Dengan kondisi ini, konsumen diperlakukan sebagai proses produksi yang tergantung pada teknologi, dan bukan sebagai entitas yang memiliki dan menentukan pilihan sebagaimana terminologi konsumen yang dipahami secara umum (Christ, 1955).

Internalisasi aspek wilayah menggiring kerangka analisis ini menjadi model Inter Regional Input Output. Dari sisi perspektif global, model ini mencakup perdagangan lintas negara. Keuntungan utama dari pengembangan analisis ini adalah kita dapat menggunakannya untuk menghitung dampak suatu guncangan yang berasal dari suatu negara atau dari sekelompok negara, terhadap negara lainnya, yang ditransmisikan melalui jaringan perdagangan global.

Paper ini menggunakan Asian International Input-Output (AIO). Tabel AIO dikompilasi dan dikeluarkan oleh Institute of Developing Economies Japan External Trade Organization (IDE-JETRO) dengan frekuensi setiap 5 tahun. Tabel ini digunakan untuk melakukan analisa struktur industri dan keterkaitan hubungan perdagangan antara perekonomian di wilayah Asia Pasifik.

Tabel AIO menyediakan informasi rinci seperti struktur internasional input dan output untuk intermediate dan final goods serta keterkaitan produksi dan perdagangan antara 9 negara di wilayah Asia Pasifik yang meliputi Indonesia, Malaysia, Filipina, Singapura, Korea Selatan, Taiwan, Thailand dan Jepang serta AS. Selain itu, tabel AIO juga menyediakan informasi perdagangan yang terdiri dari Hong Kong S.A.R, EU, dan Rest of the World (ROW) serta beberapa data perdagangan lainnya seperti yang terlihat pada Lampiran 1. Sampai dengan saat ini, tabel AIO telah dikompilasi untuk tahun 1985, 1990, dan 2000. Tabel AIO menjelaskan mengenai 
bagaimana input yang digunakan oleh industri di suatu negara terkait dengan output dari negara lain melalui sebuah fungsi koefisien. Sisi baris pada tabel AIO menggambarkan produksi (output) suatu negara yang menjadi input di negara lain.

Tabel AIO juga memiliki keterbatasan karena membutuhkan waktu dan sumber daya yang sangat besar untuk melengkapi tabel tersebut sehingga publikasinya memiliki selang waktu yang lama. Saat ini, tabel AIO terakhir yang tersedia adalah tahun 2000 yang dipublikasikan tahun 2006. Sementara itu, perekonomian dunia terus bergerak dan banyak mengalami perubahan. Sebagai contoh, saat ini perdagangan di dalam wilayah Asia Pasifik telah memasuki fase yang baru dibandingkan tahun 2000 sesuai dengan peningkatan peran China sebagai sebagai produsen terbesar. Sejalan dengan hal tersebut, maka penggunaan tabel AIO 2000 sudah dianggap tidak cocok lagi untuk dapat menganalisa keterkaitan perdagangan perekonomian wilayah Asia Pasifik saat ini. Oleh karena itu, pada penelitian ini dilakukan updating tabel AIO pada level negara dan sektoral untuk tahun 2010 serta menggunakan tabel tersebut untuk menjawab tujuan penelitian.

\subsection{Updating Tabel AIO}

Updating tabel AIO menggunakan bagan manual yang dibuat oleh Pula dan Peltonen (2007) yang juga melakukan penelitian dengan melakukan updating tabel AlO tahun 2006. Bagan tersebut telah dilengkapi dengan formula untuk memudahkan proses updating data (Lampiran 2). Paper ini melakukan updating tahun 2010 dengan menggunakan basis data tabel AIO tahun 2000. Secara umum, data tahun 2010 diperoleh dengan melakukan perkalian data tahun 2000 dengan tingkat pertumbuhan masing-masing dalam kurun waktu tahun 2000 ke 2010. Langkah dan prosedur untuk melakukan estimasi data tahun 2010 adalah dengan melakukan updating data sebagai berikut:

A. Sisi baris (Intermediate Demand)

- Value Added $\left(V_{t+1}^{j}\right)$. Tingkat pertumbuhan value added dari data national account.

- Total Output $\left(X_{t+1}^{j}\right)$. Total (Gross) Output diestimasi dengan menghitung rasio output/ value added di dalam sektor manufacturing terhadap total value added. Data value added manufacturing berasal dari national account, sedangkan data output dari industrial statistics

- Imported inputs $\left(A_{t+1}^{i j}\right)$. Perhitungan tingkat pertumbuhan imported input berasal dari dua sumber. Pertama untuk menjaga konsistensi, maka menggunakan data National Accounts yang melibatkan data perdagangan barang dan jasa, namun tidak menunjukkan informasi mengenai arah perdagangan. Oleh karena itu digunakan juga data yang berasal dari UN Comtrade yang menyediakan informasi mengenai jenis barang yang diimpor, asal dan tujuan arah perdagangan. Formula yang digunakan untuk menghitung tingkat pertumbuhan imported input tersebut adalah sebagai berikut: 
$\left(\right.$ int $M_{t+1}^{* i j}$ int $\left.M_{t}^{* i j}\right)=\left(M_{t+1}^{N A} M_{t+1}^{N A}\right) \star \frac{\left(\text { int } M_{t+1}^{C O M i j} / \text { int } M_{t}^{C O M i j}\right)}{\left(M_{t+1}^{C O M} / M_{t+1}^{C O M}\right)}$

int $M$ menunjukkan impor dari intermediate goods; $M$ menunjukkan total impor; $N A$ singkatan dari National Accounts dan COM adalah singkatan dari UN Comtrade

- Freight and insurance dan import duties $\left(B A_{t+1}^{j}, D A_{t+1}^{j}\right)$. Tingkat pertumbuhan dari freights and insurance dan import duties dianggap sama dengan tingkat pertumbuhan impor dalam National Accounts

\section{B. Sisi kolom (Final Demand)}

- Total Konsumsi dan Investasi $\left(C_{t+1}^{j}, l_{t+1}^{j}\right)$. Tingkat pertumbuhan konsumsi dan investasi diambil dari data National Accounts. Konsumsi merupakan penjumlahan dari konsumsi rumah tangga dan pemerintah, sementara investasi setara dengan gross capital formation (gross fixed capital formation ditambah inventories)

- Imported Final Goods ( $\left.\mathrm{CF}_{t+1}^{i j}\right)$ dan Imported Capital Goods $\left(\mathrm{iF}_{t+1}{ }^{i j}\right)$.

Tingkat pertumbuhan dihitung berdasarkan formula di bawah ini:

$$
\begin{aligned}
& \left(c M_{t+1}^{* i j} / c M_{t}^{* i j}\right)=\left(M_{t+1}^{N A} / M_{t+1}^{N A}\right) * \frac{\left(c M_{t+1}^{C O M i j} / c M_{t}^{C O M i j}\right)}{\left(M_{t+1}^{C O M} / M_{t+1}^{C O M}\right)} \\
& \left(\operatorname{cap}_{t+1}^{* i j} / \operatorname{cap}_{t}^{* i j}\right)=\left(M_{t+1}^{N A} / M_{t+1}^{N A}\right) * \frac{\left(\operatorname{cap}_{t+1}^{C O M i j} / \operatorname{capM}_{t}^{C O M i j}\right)}{\left(M_{t+1}^{C O M} / M_{t+1}^{C O M}\right)}
\end{aligned}
$$

NA singkatan dari National Accounts dan COM adalah singkatan dari UN Comtrade; cM dan capM masing-masing merupakan impor dari consumption dan capital goods.

\section{Kolom Export (L)}

- Export ke Hongkong, EU15 dan RoW $\left(L^{i+}{ }_{t+1}, L^{i 0}{ }_{t+1} L^{i}{ }^{i W}{ }_{t+1}\right)$. Tingkat pertumbuhan diambil dari tingkat pertumbuhan ekspor berdasarkan data UN Comtrade dan National Accounts

$$
\left(E X_{t+1}^{* i j} E X_{t}^{* i j}\right)=\left(E X_{t+1}^{N A} / E X_{t+1}^{N A}\right) \star \frac{\left(E X_{t+1}^{C O M i j} / E X_{t}^{C O M i j}\right)}{\left(E X_{t+1}^{C O M} / E X_{t+1}^{C O M}\right)}
$$

- Stastitical Discrepancy $\left(Q_{t+1}^{i}\right)$. Data diambil dari National Accounts

\section{Total Intermediate Input/Output}

Total intermediate input merupakan selisih antara Total Input dengan penjumlahan sisi baris dari Freight Insurance sampai dengan Value Added. Sedangkan total intermediate output merupakan selisih antara Total Output dengan penjumlahan sisi kolom dari Statistical Discrepancy sampai dengan Final Demand. Apabila terdapat perbedaan jumlah total intermediate input dan 
output, maka dalam penelitian ini menggunakan judgement bahwa angka total intemediate input adalah angka yang dianggap valid, sehingga selisih antara total intermediate input dan output dimasukkan ke dalam statistical discrepancy. Pada akhirnya diperoleh angka total intemediate input yang sama dengan total intemediate output.

\section{E. Intermediate Demand}

Intermediate demand setiap negara diestimasi dengan menggunakan metode RAS.

\subsection{Metode RAS}

Metode RAS merupakan metodologi yang lazim digunakan untuk memperbarui matriks koefisien pada tahun t+1 dalam melakukan analisa input output ${ }^{2}$. Metode ini pada intinya mencari matriks Leontief yang sesuai sehingga set of intermediate input/output memiliki jumlah yang konsisten pada periode $t+1$. Matriks koefisien yang telah diperbarui melalui metode ini telah memfasilitasi perubahan teknologi, perubahan harga relatif, dan ketidaksempurnaan data.

Dasar dan asumsi yang digunakan dalam metode RAS adalah:

- Tersedianya matriks 10 yang telah diestimasi dari tahun sebelumnya $\left(\mathrm{t}_{0}\right)$

- Tersedia data sisi baris dan kolom dari tahun yang akan diestimasi

- Mencari serangkaian multiplier untuk menyesuaikan sisi baris dan kolom sehingga sesuai dengan target total intermediate input/output tahun yang akan diestimasi

Metode RAS secara sederhana dapat diuraikan sebagai berikut:

$$
\begin{aligned}
A_{1} & =\hat{r} A_{0} \hat{s} \\
& =\left[\begin{array}{ll}
r_{1} & 0 \\
0 & r_{2}
\end{array}\right] \times\left[\begin{array}{ll}
a_{11} & a_{12} \\
a_{21} & a_{22}
\end{array}\right] \times\left[\begin{array}{cc}
s_{1} & 0 \\
0 & s_{2}
\end{array}\right]=\left[\begin{array}{cc}
r_{1} a_{11} s_{1} & r_{1} a_{12} s_{2} \\
r_{2} a_{12} s_{1} & r_{2} a_{22} s_{2}
\end{array}\right] \\
F_{1} & =A_{1} \widehat{X_{1}}=\left(\hat{r} A_{0} \hat{s}\right) \widehat{X_{1}} \\
u^{*} & =F_{1} i \\
& \left.=\widehat{r} A_{0} \widehat{s}\right) \widehat{X_{1}} i \\
& \left.=\hat{r} A_{0} \widehat{X_{1}}\right) \hat{s} i \\
& =\hat{r}\left(A_{0} \widehat{X_{1}}\right) s
\end{aligned}
$$

2 Buetre dan Esfahani (2000). Updating an Input Output Table for Use in Policy Analysis. The Australian Journal of Agricultural and Resource Economics 


$$
\begin{aligned}
& v^{*}=F_{1} i \\
& v^{* *}=i^{\prime} F_{1} \\
& v^{*}=r^{\prime}\left(A_{0} \widehat{X_{1}}\right) \hat{s}
\end{aligned}
$$

Notasi dari formula metode RAS di atas mencakup $\mathrm{F}_{0}=$ Matriks $\mathrm{IO}$ yang menjadi benchmark; $F_{1}=$ Matriks 10 yang telah diperbarui; $A_{0}=$ Koefisien matriks 10 yang menjadi benchmark; $A_{1}=$ Koefisien matriks IO yang telah diperbarui; $r \& s=$ Multiplier sisi baris dan kolom; $X_{1}=$ Vektor output dari tahun terbaru; $u^{*} \& v^{*}=$ sisi baris dan kolom total intermediate input dan ouput dari matriks tahun terbaru; $i$ adalah vektor kolom dimana setiap angka setara dengan 1.

Tahap berikutnya adalah langkah-langkah metode RAS yang secara sederhana di jelaskan

\begin{tabular}{|c|c|c|c|c|c|c|}
\hline \multicolumn{7}{|c|}{$\begin{array}{c}\text { Tabel } 1 \\
\text { Tabel IO Tahun } 0\left(F_{0}\right)\end{array}$} \\
\hline \multirow[b]{2}{*}{ Negara } & \multicolumn{3}{|c|}{ Intermediate Demand } & \multirow{2}{*}{$\begin{array}{c}\text { Total } \\
\text { Int.Output }\end{array}$} & \multirow{2}{*}{$\begin{array}{l}\text { Final } \\
\text { Demand }\end{array}$} & \multirow{2}{*}{$\begin{array}{l}\text { Total } \\
\text { Output }\end{array}$} \\
\hline & A & B & C & & & \\
\hline A & 50 & 100 & 0 & 150 & 50 & 200 \\
\hline B & 30 & 50 & 20 & 100 & 200 & 300 \\
\hline C & 20 & 50 & 30 & 100 & 100 & 200 \\
\hline $\begin{array}{c}\text { Total } \\
\text { Int.Input }\end{array}$ & 100 & 200 & 50 & 350 & 350 & 700 \\
\hline $\begin{array}{l}\text { Value } \\
\text { Added }\end{array}$ & 100 & 100 & 150 & 350 & & \\
\hline Total Input & 200 & 300 & 200 & 700 & & \\
\hline
\end{tabular}
sebagai berikut ${ }^{3}$ :

1. Tersedianya tabel 10 tahun 0

3 Langkah-langkah metode RAS diambil dari presentasi Capilit. E (Asian Development Bank) pada 2 ${ }^{\text {nd }}$ Data Review Workshop, tanggal 7-12 Desember 2009. 
2. Updating data tabel 10 tahun 1

\begin{tabular}{|c|c|c|c|c|c|c|}
\hline \multicolumn{7}{|c|}{$\begin{array}{c}\text { Tabel } 2 \\
\text { Tabel IO Tahun } 1\left(F_{1}\right)\end{array}$} \\
\hline \multirow[b]{2}{*}{ Negara } & \multicolumn{3}{|c|}{ Intermediate Demand } & \multirow{2}{*}{$\begin{array}{c}\text { Total } \\
\text { Int.Output }\end{array}$} & \multirow{2}{*}{$\begin{array}{c}\text { Final } \\
\text { Demand }\end{array}$} & \multirow{2}{*}{$\begin{array}{c}\text { Total } \\
\text { Output }\end{array}$} \\
\hline & A & B & C & & & \\
\hline A & & & & 160 & 40 & 200 \\
\hline B & & & & 150 & 250 & 400 \\
\hline C & & & & 120 & 180 & 300 \\
\hline $\begin{array}{c}\text { Total } \\
\text { Int.Input }\end{array}$ & 100 & 250 & 80 & 430 & 470 & 900 \\
\hline $\begin{array}{l}\text { Value } \\
\text { Added }\end{array}$ & 100 & 150 & 220 & 470 & & \\
\hline Total Input & 200 & 400 & 300 & 900 & & \\
\hline
\end{tabular}

3. Mencari koefisien matriks di tahun 0

\begin{tabular}{c|c|c|c}
\multicolumn{4}{c}{ Tabel 3 } \\
\multicolumn{1}{|c}{ Koefisien Matriks Tahun 0} \\
& \multicolumn{2}{|c}{ Intermediate Demand } \\
\hline Negara & A & B & C \\
\hline A & 0,250 & 0,333 & 0,000 \\
\hline B & 0,150 & 0,167 & 0,100 \\
\hline C & 0,100 & 0,167 & 0,150 \\
\hline
\end{tabular}

4. Koefisien matriks di tahun 0 dikali dengan Total Input pada tabel IO tahun 1 untuk mengisi intermediate demand di tahun 1. Kemudian dilakukan penjumlahan pada setiap sisi baris dan dibandingkan dengan target total intermediate output sehingga diperoleh rasio $\mathrm{r}^{1}$

\begin{tabular}{|c|c|c|c|c|c|c|}
\hline \multicolumn{7}{|c|}{$\begin{array}{c}\text { Tabel } 4 \\
\text { Koefisien Matriks di Tahun } 0 \text { Dikali dengan Total Output }\end{array}$} \\
\hline \multirow[b]{2}{*}{ Negara } & \multicolumn{3}{|c|}{ Intermediate Demand } & \multirow[b]{2}{*}{$u_{1}$} & \multirow[b]{2}{*}{$\mathbf{u}^{*}$} & \multirow[b]{2}{*}{$r_{1}=u^{*} / u_{1}$} \\
\hline & A & B & C & & & \\
\hline A & 50,0 & 133,3 & 0,0 & 183,33 & 160 & 0,873 \\
\hline B & 30,0 & 66,7 & 30,0 & 126,67 & 150 & 1,184 \\
\hline C & 20,0 & 66,7 & 45,0 & 131,67 & 120 & 0,911 \\
\hline
\end{tabular}


5. Rasio $r_{1}$ yang telah diperoleh dikali dengan setiap angka pada sisi baris sehingga penjumlahan sisi baris menjadi sama dengan target total intermediate output

\begin{tabular}{|c|c|c|c|c|}
\hline \multicolumn{5}{|c|}{$\begin{array}{c}\text { Tabel } 5 \\
\text { Penyesuaian Sisi Baris sesuai Rasio } r_{1}\end{array}$} \\
\hline \multirow[b]{2}{*}{ Negara } & \multicolumn{3}{|c|}{ Intermediate Demand } & \multirow[b]{2}{*}{$\mathrm{u}_{1}=\mathrm{u}$} \\
\hline & A & B & C & \\
\hline A & 43,6 & 116,4 & 0,0 & 160 \\
\hline B & 35,5 & 78,9 & 35,5 & 150 \\
\hline C & 18,2 & 60,8 & 41,0 & 120 \\
\hline
\end{tabular}

6. Dilakukan penjumlahan pada setiap sisi kolom dan dibandingkan dengan target total intermediate input sehingga diperoleh rasio $\mathrm{s}_{1}$

\begin{tabular}{|c|c|c|c|}
\hline \multicolumn{4}{|c|}{$\begin{array}{c}\text { Tabel } 6 \text { Penjumlahan Sisi Kolom dan } \\
\text { Diperoleh Rasio } s_{1}\end{array}$} \\
\hline & \multicolumn{3}{|c|}{ Intermediate Demand } \\
\hline Negara & A & B & C \\
\hline A & 43,6 & 116,4 & 0,0 \\
\hline B & 35,5 & 78,9 & 35,5 \\
\hline C & 18,2 & 60,8 & 41,0 \\
\hline v1 & 97,4 & 256,1 & 76,5 \\
\hline $\mathbf{v}^{*}$ & 100 & 250 & 80 \\
\hline$s_{1}=v^{*} / v_{1}$ & 1,027 & 0,976 & 1,045 \\
\hline
\end{tabular}

7. Rasio $s_{1}$ yang telah diperoleh dikali dengan setiap angka pada sisi kolom sehingga penjumlahan sisi kolom menjadi sama dengan target total intermediate input

\begin{tabular}{|c|c|c|c|}
\hline \multicolumn{4}{|c|}{$\begin{array}{c}\text { Tabel } 7 \text { Penyesuaian Sisi Kolom } \\
\text { sesuai Rasio } s_{1}\end{array}$} \\
\hline & \multicolumn{3}{|c|}{ Intermediate Demand } \\
\hline Negara & A & B & C \\
\hline A & 44,8 & 113,6 & 0,0 \\
\hline B & 36,5 & 77,1 & 37,1 \\
\hline C & 18,7 & 59,3 & 42,9 \\
\hline$v^{*}=v_{1}$ & 100 & 250 & 80 \\
\hline
\end{tabular}


8. Melakukan iterasi langkah 5 sampai 7 sehingga pada akhirnya diperoleh rasio $\mathrm{r}_{1}$ dan $\mathrm{s}_{1}$ yang mendekati 1

\begin{tabular}{|c|c|c|c|c|c|}
\hline \multicolumn{6}{|c|}{$\begin{array}{c}\text { Tabel } 8 \text { Penyesuaian Kolom dan Baris sampai } u=u^{*} \text { dan } v=v^{*} \\
\text { dalam Matriks Akhir }\end{array}$} \\
\hline & \multicolumn{3}{|c|}{ Intermediate Demand } & \multirow[b]{2}{*}{$u_{1}=u$} & \multirow[b]{2}{*}{$r_{1}=u^{*} / u_{1}$} \\
\hline Negara & A & B & C & & \\
\hline A & 45,3 & 114,7 & 0,0 & 160 & 0,884 \\
\hline B & 36,2 & 76,6 & 37,2 & 150 & 1,177 \\
\hline C & 18,5 & 58,7 & 42,8 & 120 & 0,902 \\
\hline$v^{*}=v_{1}$ & 100 & 250 & 80 & & \\
\hline$s_{1}=v^{*} / v_{1}$ & 1,025 & 0,974 & 1,054 & & \\
\hline
\end{tabular}

\subsection{Keterkaitan Backward dan Forward (Backward and Forward Linkage)}

Keterkaitan backward dan forward dalam produksi diukur dengan menggunakan koefisien leontief. Koefisien leontief pada tabel AIO dapat dihitung sebagai berikut:

$$
a_{i j}=\frac{A_{i j}}{X_{j}}
$$

dimana $i=$ negara asal; $j$ = negara tujuan; $A_{\mathrm{ij}}$ adalah input dari negara asal yang digunakan oleh negara $j$; dan $X_{i}$ adalah total produksi dari negara $j$. Sehingga tabel AlO dapat ditulis sebagai berikut:

$$
\left[\begin{array}{cccc}
\alpha^{I I} & \alpha^{I M} & \cdot & \alpha^{I U} \\
\alpha^{M I} & \alpha^{M I} & \cdot & \alpha^{M U} \\
\cdot & \cdot & \cdot & \cdot \\
\alpha^{U I} & \alpha^{U M} & \cdot & \alpha^{U U}
\end{array}\right] \times\left[\begin{array}{c}
X^{I} \\
X^{M} \\
\cdot \\
X^{U}
\end{array}\right]+\left[\begin{array}{c}
F^{I I} \\
F^{M I} \\
\cdot \\
F^{U I}
\end{array}\right]+\left[\begin{array}{c}
F^{I M} \\
F^{M M} \\
\cdot \\
F^{U M}
\end{array}\right]+\ldots+\left[\begin{array}{c}
Q^{I} \\
Q^{M} \\
\cdot \\
Q^{U}
\end{array}\right]=\left[\begin{array}{c}
X^{I} \\
X^{M} \\
\cdot \\
X^{U}
\end{array}\right]
$$

Untuk $\mathrm{F}^{\mathrm{ij}}=$ vektor dari final demand (jumlah dari konsumsi dan investasi); dan Q's = vektor ekspor ke Hongkong, EU, Rest of the World. Matriks notasi di atas dapat ditulis secara ringkas sebagai berikut:

$$
\mathrm{AX}+\mathrm{Y}=\mathrm{X}
$$

Untuk melihat seberapa banyak input yang dibutuhkan untuk menghasilkan satu output adalah sebagai berikut:

$$
\mathrm{X}=(1-\mathrm{A})^{-1} \mathrm{Y}=\mathrm{BY}, \mathrm{B} \text { merupakan matriks koefisien leontief }
$$


$\mathrm{B}^{\mathrm{ij}}$ merupakan bagian dari matriks yang menunjukkan jumlah produksi yang dibutuhkan oleh negara $i$ (negara asal) untuk menghasilkan satu unit nilai tambah di negara $j$ (negara tujuan). Matriks koefisien leontief dapat membantu analisis keterkaitan produksi antar negara melalui perdagangan intermediate goods.

\section{METODOLOGI}

Sebagaimana diuraikan sebelumnya, model yang digunakan dalam paper ini adalah model Inter Regional Input Output. Data yang digunakan antara lain bersumber dari Tabel Asian International Input Output (AIO) yang dikompilasi oleh Institute of Developing Economies Japan External Trade Organization (IDE-JETRO). AIO menunjukkan perdagangan intermediate dan final demand 10 negara, meliputi: Indonesia, Malaysia, Filipina, Thailand, Singapura, China, Taiwan, Jepang, Korea Selatan, dan AS. Tabel tersebut tersedia dengan frekuensi 5 tahunan mulai dari tahun 1985,1990, 1995, dan 2000.

Guna updating data pada tabel AIO 2010, digunakan data export import 9 negara ${ }^{4}$ serta Hongkong, EU dan Rest of the World berdasarkan jenis barang serta asal dana negara tujuan yang berasal dari UNComtrade dari tahun 2000-2010. Data produksi sektor manufaktur, GDP, serta beberapa data penunjang lainnya diambil dari CEIC.

Khusus untuk data perdagangan Hongkong, dilakukan beberapa penyesuaian berikut. Berdasarkan data statistik perdagangan Hongkong, komponen re-export pada tahun 2010 mencapai 97,7\% dari total export. Re-export meliputi produk-produk yang melewati Hongkong tanpa melalui proses manufaktur yang dapat mengubah bentuk, ukuran maupun fungsi dari produk tersebut. Re-export yang dilakukan oleh Hongkong erat kaitannya dengan perdagangan yang dilakukan antara China dan negara partner dagangnya. Sehingga apabila tidak dikoreksi, angka perdagangan jauh lebih tinggi dari aktual.

Data perdagangan Hongkong menyediakan informasi yang mencakup re-export berdasarkan negara asal dan tujuan serta jenis produk. Berdasarkan informasi tersebut, untuk menyesuaikan impor dari intermediate, consumer dan capital goods Hongkong digunakan formula sebagai berikut:

$$
\begin{aligned}
& A_{H K}^{i j}=A^{i j}+\eta_{\text {int }}^{j} \star \gamma^{i j} \star L H^{i} \\
& C F_{H K}^{i j}=C F^{i j}+\eta_{\text {cons }}^{j} \star \gamma^{i j} \star L H^{i} \\
& i F_{H K}^{i j}=i F^{i j}+\eta_{\text {cap }}^{j} \star \gamma^{i j} \star L H^{i}
\end{aligned}
$$

4 Data perdagangan Taiwan tidak tersedia dalam UNComtrade. 


$$
\begin{gathered}
\gamma^{i j}=\frac{R X^{* i j}}{M^{* i}} \\
\eta_{g}^{j}=\frac{R X_{g}^{* j}}{R X^{* j}}
\end{gathered}
$$

Dimana LH' merupakan export negara $i$ ke Hongkong; y $y^{i j}$ merupakan share yang diperoleh dari nilai re-export Hong Kong dari negara $i$ (asal) ke negara $j$ (tujuan), kemudian dibagi dengan total import Hongkong dari negara $i$ tersebut; dan $\eta_{\mathrm{g}}^{\mathrm{j}}$ merupakan share jenis produk $g$ (intermediate, consumption dan capital goods), terhadap total re-export ke negara $j$.

\section{HASIL DAN ANALISIS}

Dengan menggunakan tabel AIO tahun 2010 yang telah di update dengan menggunakan metode RAS, bagian ini akan melakukan analisa dalam ke dua bagian; pertama, analisa koefisien backward dan forward linkage; dan kedua, analisa ketergantungan value added suatu negara terhadap permintaan domestik, intra-regional trade, maupun perdagangan dengan negara maju. Selain itu, dalam bagian ini akan dilakukan analisa berdasarkan 24 sektor dalam setiap negara, termasuk simulasi perlambatan PDB atau ekspor negara AS, EU, dan China. Di akhir bagian dalam bab ini akan dilakukan robustness check untuk konsistensi angka yang dihasilkan dari Tabel AIO 2010.

\subsection{Asian IO Agregat: Backward dan Forward Linkages}

Backward linkages (BL) merupakan koefisien yang digunakan untuk melihat seberapa besar input yang diperoleh dari negara lain yang digunakan untuk menghasilkan output di dalam negeri atau seringkali disebut seberapa besar import content suatu negara. Dari Tabel 9 terlihat koefisien BL yang dihitung dengan menggunakan 10 tahun 2000 dan 2010. Indonesia memiliki nilai BL yang meningkat apabila dibandingkan dengan tahun 2000 (1,72 menjadi 1,87).

Ketergantungan yang meningkat pesat terhadap output negara lain dialami oleh China. Pada tahun 2000, China memiliki BL sebesar 2,57, hampir setara dengan Jepang dan AS, akan tetapi saat ini China memiliki koefisien BL sebesar 5,20. Angka ini menunjukkan ketergantungan China yang besar dengan negara lain dalam kegiatan produksinya terutama untuk intermediate goods. Sementara penurunan import content Jepang diduga karena perlambatan PDB. Sehingga kegiatan produksi yang melambat, maka kebutuhan akan barang intermediate menjadi semakin melambat. 


\begin{tabular}{|c|c|c|}
\multicolumn{3}{|c|}{ Tabel 9 } \\
Koefisien Backward Linkages \\
\hline Negara & $\mathbf{2 0 0 0}$ & $\mathbf{2 0 1 0}$ \\
\hline Indonesia & 1,72 & 1,87 \\
Malaysia & 1,64 & 1,47 \\
Filipina & 1,50 & 1,69 \\
Singapura & 1,73 & 1,43 \\
Thailand & 1,73 & 2,17 \\
China & 2,57 & 5,20 \\
Taiwan & 1,73 & 2,17 \\
Korea & 1,95 & 2,38 \\
Jepang & 2,46 & 1,81 \\
U.S.A. & 2,19 & 2,32 \\
\hline
\end{tabular}

\begin{tabular}{|c|c|c|}
\multicolumn{3}{|c|}{ Tabel 10 } \\
Koefisien Forward Linkages \\
Negara & $\mathbf{2 0 0 0}$ & $\mathbf{2 0 1 0}$ \\
\hline Indonesia & 1,74 & 1,85 \\
Malaysia & 2,01 & 1,75 \\
Philippines & 1,76 & 1,83 \\
Singapore & 1,99 & 1,68 \\
Thailand & 1,92 & 2,60 \\
China & 2,48 & 4,66 \\
Taiwan & 1,86 & 2,55 \\
Korea & 1,93 & 2,44 \\
Japan & 1,79 & 1,48 \\
U.S.A. & 1,74 & 1,69 \\
\hline
\end{tabular}

Di sisi lain, Tabel 10 menunjukkan besar koefisien forward linkages (FL) setiap negara, yang artinya seberapa besar output yang dihasilkan dalam negeri menjadi input bagi kegiatan produksi di negara lain (ekspor barang intermediate). Dari koefisien $\mathrm{FL}$, Indonesia mengalami peningkatan ekspor barang intermediate dari koefisien tahun 2000 sebesar 1,74 menjadi 1,85. Kenaikan ini juga dialami oleh negara Asia Tenggara lainnya, seperti Filipina dan Thailand.

Sementara China yang memiliki koefisien FL yang terbesar pada tahun 2000 yaitu sebesar 2.48, mengalami peningkatan yang pesat pada koefisien FL di tahun 2010 menjadi 4,66. Hal ini menunjukkan selain China memiliki ketergantungan yang tinggi terhadap barang intermediate, China juga melakukan kegiatan ekspor barang intermediate yang besar.

Perdagangan internasional menjadi sumber utama pertumbuhan ekonomi dunia. Pola hubungan dan keterkaitan ekonomi antar negara dipengaruhi oleh berbagai faktor, salah satunya adalah jalur perdagangan. Nilai perdagangan dunia yang dihitung dari rasio total ekspor dan impor barang terhadap PDB menunjukkan tren yang terus meningkat dari sekitar 37\% tahun 1980 menjadi lebih dari 51,5\% tahun 2011 (Grafik 1). Indikator tersebut menunjukkan bahwa derajat keterbukaan ekonomi dunia secara umum menunjukkan perkembangan yang semakin terbuka dan saling terkait.

Negara maju masih mempunyai pangsa eksternal trade lebih besar dibanding kelompok negara lainnya. Sementara, meskipun memiliki porsi yang relatif kecil, negara berkembang Asia menunjukkan perkembangan yang akseleratif dibanding kawasan lainnya. Pangsa ekspor impor kawasan berkembang Asia terhadap PDB dunia melonjak cukup signifikan atau hampir 5 kali lipat dibanding pada 1980 atau menjadi 9\%. Penyumbang kenaikan terbesar berasal dari China, sementara dalam ukuran yang moderat bersumber dari India, Malaysia, Thailand, dan Indonesia. 


\begin{tabular}{|c|c|c|c|c|c|c|c|c|}
\hline \multicolumn{9}{|c|}{$\begin{array}{c}\text { Tabel } 11 \\
\text { Perkembangan Ekonomi Dunia }\end{array}$} \\
\hline \multicolumn{2}{|l|}{ Indikator Utama Dunia } & 2000 & 2005 & 2008 & 2009 & 2010 & 2011 & 2012 * \\
\hline PDB Dunia & & & & & & & & \\
\hline Dunia & $\%$ & 4,7 & 4,5 & 2,8 & $-0,6$ & 5,3 & 3,9 & 3,5 \\
\hline Advanced economies & $\%$ & 4,1 & 2,6 & 0,0 & $-3,6$ & 3,2 & 1,6 & 1,4 \\
\hline Euro area & $\%$ & 3,8 & 1,7 & 0,4 & $-4,3$ & 1,9 & 1,4 & $-0,3$ \\
\hline Emerg. \& Dev'ing ec. & $\%$ & 5,8 & 7,3 & 6,0 & 2,8 & 7,5 & 6,2 & 5,7 \\
\hline Berkembang Asia & $\%$ & 6,7 & 9,5 & 7,8 & 7,1 & 9,7 & 7,8 & 7,3 \\
\hline ASEAN-5 & $\%$ & 5,3 & 5,5 & 4,8 & 1,7 & 7,0 & 4,5 & 5,4 \\
\hline AS & $\%$ & 4,1 & 3,1 & $-0,3$ & $-3,5$ & 3,0 & 1,7 & 2,1 \\
\hline Jepang & $\%$ & 2,3 & 1,3 & $-1,0$ & $-5,5$ & 4,4 & $-0,7$ & 2,0 \\
\hline Jerman & $\%$ & 3,3 & 0,8 & 0,8 & $-5,1$ & 3,6 & 3,1 & 0,6 \\
\hline China & $\%$ & 8,4 & 11,3 & 9,6 & 9,2 & 10,4 & 9,2 & 8,2 \\
\hline India & $\%$ & 5,2 & 9,0 & 6,2 & 6,6 & 10,6 & 7,2 & 6,9 \\
\hline Indonesia & $\%$ & 4,2 & 5,7 & 6,0 & 4,6 & 6,2 & 6,5 & 6,1 \\
\hline Perdagangan dan Harga & & & & & & & & \\
\hline WTV & $\%$ & 12,3 & 7,8 & 2,9 & $-10,5$ & 12,9 & 5,8 & 4,0 \\
\hline Inflasi & $\%$ & 4,5 & 3,8 & 4,4 & 3,1 & 4,2 & 4,4 & 4,0 \\
\hline Harga Komoditas & $\%$ & 26,7 & 24,2 & 27,6 & $-30,0$ & 26,1 & 26,1 & 2,1 \\
\hline Harga minyak & $\%$ & 57,0 & 41,3 & 36,4 & $-36,3$ & 27,9 & 31,6 & 10,3 \\
\hline
\end{tabular}

Meskipun peranan perdagangan internasional dari China berkembang pesat, komposisi rasio ekspor dan impor terhadap PDB China tidak terlalu besar. Rasio ekspor impor terhadap PDB tahun 2011 masih sekitar 50\% atau jauh dibawah negara seperti Singapura (298\%), Malaysia (149\%) (Grafik 2). Hal ini sejalan dengan tipikal negara dengan populasi besar biasanya ditandai oleh peranan permintaan domestik yang lebih menonjol. India, AS, dan Indonesia masing-masing memiliki rasio derajat keterbukaan sebesar 44,5\%, 24,8\%, dan 44,7\%. Siklus ekonomi dunia terutama yang bersumber dari negara maju, berpotensi besar akan ditransmisikan secara lebih

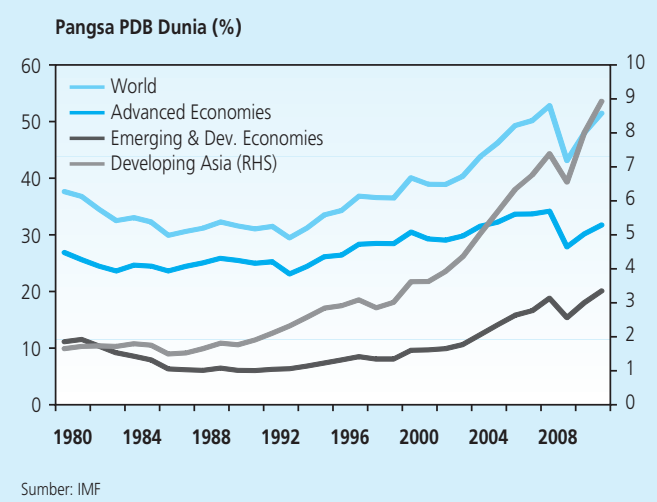

Grafik 1. Perkembangan Rasio Perdagangan Internasional per Kawasan (\% PDB)

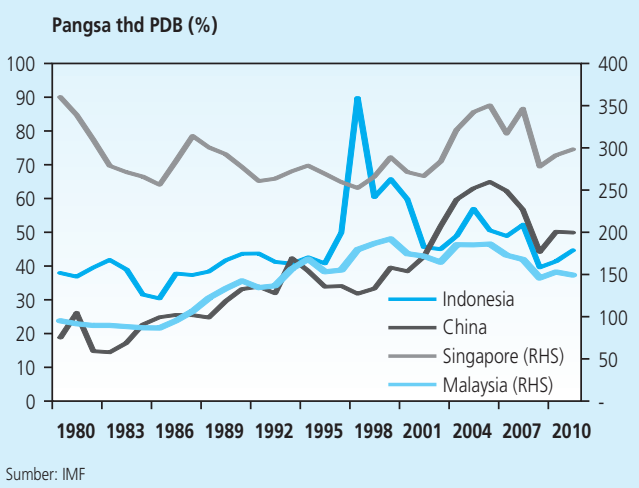

Grafik 2. Perkembangan Rasio Perdagangan Internasional per PDB VS Rating 
besar kepada negara yang mempunyai derajat rasio keterbukaan ekonomi yang relatif tinggi. Dengan melihat data ekonomi China, potensi transmisi tersebut relatif tidak terlalu besar dibandingkan dengan Singapura.

Sebagai contoh, dari Tabel 11 terlihat bahwa, meskipun PDB negara di kawasan negara maju, baik di AS maupun kawasan Euro terjadi kontraksi di tahun 2009, ekonomi China masih tetap tumbuh cukup tinggi mencapai 9,2\% (Grafik 3). Struktur PDB yang lebih bersandar kepada sumber domestik seperti investasi dan konsumsi menjadi sumber penahan kejatuhan ekspor (permintaan eksternal). Struktur serupa ditemui juga dalam perekonomian Indonesia, yang saat itu tumbuh sebesar 4,6\% (Grafik 4). Pada sekitar tahun 2009 dan 2010 tersebut banyak asesmen yang mengaitkan gejala decoupling ekonomi Asia dan China sebagai penggerak baru ekonomi dunia.

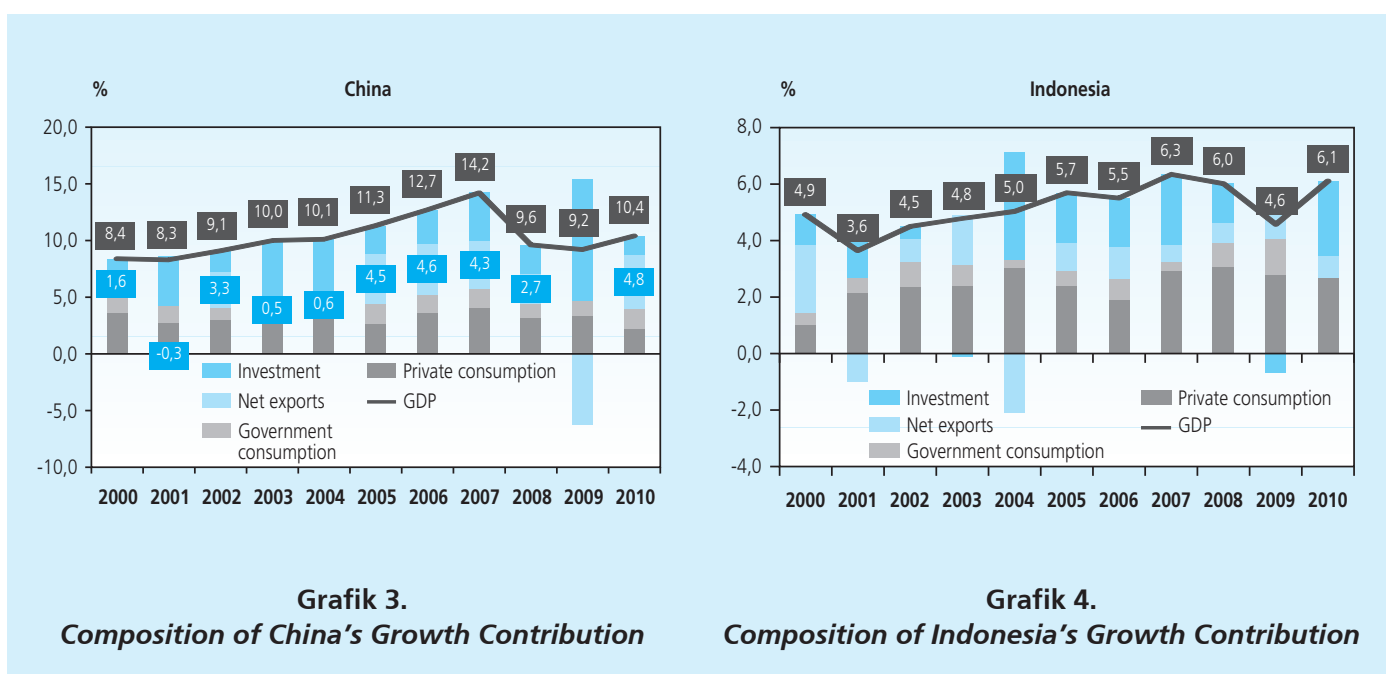

Kedua hasil perhitungan koefisien mengkonfirmasi deskripsi di atas. Kita dapat menganalisa lebih jauh dengan memetakan matrik hubungan bilateral antar negara sebagaimana disajikan dalam Tabel 12 dan 13. Dari tabel tersebut dapat terlihat bahwa pada tahun 2010, production network negara Asian IO telah banyak mengalami perubahan. Tabel 12 menunjukkan bahwa negara Asia, termasuk Indonesia, memiliki keterkaitan yang kuat dengan negara maju seperti Jepang dan AS.

Untuk kondisi tahun 2010, terdapat dua hal penting; pertama, supplier sudah terkonsentrasi dengan tinggi di wilayah Asia. Saat ini semua negara di Asia termasuk AS dan Jepang menggunakan intermediate output dari China, diikuti oleh Korea, Jepang, dan Singapura. Kedua, ketergantungan dari supplier utama mengalami perubahan yang dulu berasal negara Jepang dan AS, saat ini sudah berpindah ke China. Hal ini dapat terjadi bukan saja karena 
pertumbuhan ekonomi, khususnya sektor manufaktur China yang tinggi, tetapi juga karena beberapa perusahaan di AS dan Jepang melakukan kegiatan delokalisasi pabriknya ke daerahdaerah yang menjadi target pasar, sehingga barang yang keluar masuk ke dalam suatu negara tidak melalui perdagangan internasional.

Indonesia relatif memiliki jaringan produksi (production network) yang lemah dengan negara lain. Meski demikian saat ini Indonesia memiliki sebaran keterkaitan yang lebih lebar. Pada tahun 2000, keterkaitan Indonesia yang lebih kuat adalah ke negara tetangga, seperti Malaysia dan Singapura. Tetapi pada tahun 2010, keterkaitan input Indonesia yang lebih kuat adalah ke negara Taiwan dan Korea.

\begin{tabular}{|c|c|c|c|c|c|c|c|c|c|c|c|}
\hline \multicolumn{12}{|c|}{$\begin{array}{c}\text { Tabel } 12 \\
\text { Keterkaitan Negara Asian IO Tahun } 2000\end{array}$} \\
\hline \multicolumn{12}{|c|}{ USER } \\
\hline \multirow{11}{*}{$\frac{\frac{\sqrt{4}}{\Delta !}}{\frac{n}{\frac{n}{5}}}$} & & Indonesia & Malaysia & Filipina & Singapura & Thailand & China & Taiwan & Korea & Jepang & U.S.A. \\
\hline & Indonesia & & 0,018 & 0,011 & 0,015 & 0,011 & 0,004 & 0,010 & 0,011 & 0,004 & \\
\hline & Malaysia & 0,009 & & 0,017 & 0,082 & 0,022 & 0,005 & 0,015 & 0,009 & 0,003 & 0,001 \\
\hline & Filipina & 0,001 & 0,013 & & 0,003 & 0,004 & 0,001 & 0,007 & 0,002 & 0,001 & 0,002 \\
\hline & Singapura & 0,007 & 0,095 & 0,029 & & 0,021 & 0,005 & 0,014 & 0,006 & 0,001 & 0,001 \\
\hline & Thailand & 0,006 & 0,035 & 0,013 & 0,023 & & 0,004 & 0,008 & 0,003 & 0,002 & 0,002 \\
\hline & China & 0,017 & 0,039 & 0,018 & 0,046 & 0,035 & & 0,024 & 0,028 & 0,008 & 0,001 \\
\hline & Taiwan & 0,007 & 0,043 & 0,021 & 0,021 & 0,019 & 0,023 & & 0,009 & 0,004 & 0,006 \\
\hline & Korea & 0,013 & 0,036 & 0,034 & 0,026 & 0,020 & 0,026 & 0,030 & & 0,005 & 0,003 \\
\hline & Jepang & 0,031 & 0,148 & 0,087 & 0,133 & 0,102 & 0,039 & 0,104 & 0,057 & & 0,004 \\
\hline & U.S.A. & 0,021 & 0,113 & 0,065 & 0,090 & 0,048 & 0,020 & 0,060 & 0,051 & 0,014 & 0,011 \\
\hline
\end{tabular}

\begin{tabular}{|c|c|c|c|c|c|c|c|c|c|c|c|}
\hline & & & & Keterkaitan & $\begin{array}{r}\text { Tabel } \\
\text { Negara As }\end{array}$ & $\begin{array}{l}13 \\
\operatorname{sian} 10 \mathrm{~T}\end{array}$ & hun 20 & & & & \\
\hline & & & & & USEF & & & & & & \\
\hline & & Indonesia & Malaysia & Philippines & Singapore & Thailand & China & Taiwan & Korea & Japan & U.S.A. \\
\hline & Indonesia & & 0,019 & 0,011 & 0,016 & 0,027 & 0,011 & 0,028 & 0,023 & 0,006 & \\
\hline & Malaysia & 0,006 & & 0,010 & 0,051 & 0,031 & 0,007 & 0,024 & 0,011 & 0,002 & 0,001 \\
\hline & Philippines & 0,001 & 0,020 & & 0,004 & 0,014 & 0,005 & 0,028 & 0,007 & 0,002 & 0,001 \\
\hline 邑 & Singapore & 0,004 & 0,046 & 0,013 & & 0,023 & 0,005 & 0,017 & 0,006 & 0,001 & 0,002 \\
\hline $\overrightarrow{0}$ & Thailand & 0,006 & 0,032 & 0,011 & 0,021 & & 0,008 & 0,019 & 0,006 & 0,002 & 0,001 \\
\hline ॐ & China & 0,043 & 0,085 & 0,038 & 0,101 & 0,178 & & 0,138 & 0,121 & 0,024 & 0,001 \\
\hline & Taiwan & 0,007 & 0,036 & 0,017 & 0,017 & 0,036 & 0,042 & & 0,015 & 0,004 & 0,014 \\
\hline & Korea & 0,014 & 0,033 & 0,030 & 0,024 & 0,041 & 0,051 & 0,069 & & 0,006 & 0,003 \\
\hline & Japan & 0,013 & 0,053 & 0,030 & 0,047 & 0,082 & 0,031 & 0,095 & 0,040 & & 0,003 \\
\hline & U.S.A. & 0,022 & 0,103 & 0,057 & 0,082 & 0,100 & 0,042 & 0,141 & 0,093 & 0,017 & 0,004 \\
\hline
\end{tabular}


Hasil perhitungan koefisien BL dan FL, terutama untuk Indonesia, menunjukkan sejumlah implikasi. Kegiatan produksi Indonesia didukung oleh perdagangan eksternal dan juga peran domestik, tetapi kegiatan produksi yang dilakukan belum memberikan nilai tambah yang optimal, karena Indonesia masih cenderung melakukan ekspor barang intermediate. Lebih jauh lagi, dengan karakteristik tersebut, kegiatan ekspor Indonesia memiliki kerentanan yang tinggi terhadap produksi/permintaan partner dagang.

\subsection{AIO Agregat: Tingkat Ketergantungan Value Added Negara}

Pada analisa sebelumnya (BL dan FL), keterkaitan antar negara hanya sebatas aliran barang intermediate, pada bagian ini akan dilakukan analisa seberapa besar peran final demand (baik domestic demand maupun external trade) dalam meningkatkan value added suatu negara. Hasil perhitungan kontribusi dan dampak final demand terhadap value added disajikan pada tabel berikut.

\section{Tabel 14 \\ Kontribusi Final Demand terhadap Value Added 2010}

Tabel (a) Dampak Permintaan Akhir terhadap Nilai Tambah, Indonesia

\begin{tabular}{c|c|c} 
Permintaan Domestik & $\mathbf{2 0 0 0}$ & $\mathbf{2 0 1 0}$ \\
Perdagangan Asia Tenggara & $90,3 \%$ & $91,4 \%$ \\
Jepang & $1,2 \%$ & $1,4 \%$ \\
Cina & $2,2 \%$ & $2,3 \%$ \\
AS & $2,4 \%$ & $1,8 \%$ \\
& $2,1 \%$ & $1,9 \%$
\end{tabular}

Tabel (b) Dampak Permintaan Akhir Nilai terhadap Nilai Tambah, China

\begin{tabular}{c|c|c} 
Permintaan Domestik & $\mathbf{2 0 0 0}$ & $\mathbf{2 0 1 0}$ \\
Perdagangan Asia Tenggara & $93,2 \%$ & $87,6 \%$ \\
Jepang & $1,0 \%$ & $2,1 \%$ \\
AS & $1,3 \%$ & $2,9 \%$ \\
& $1,6 \%$ & $3,1 \%$
\end{tabular}

Hasil perhitungan pada tabel 14 menunjukkan bahwa Indonesia memiliki ketergantungan yang tinggi terhadap permintaan domestik. Pada tahun 2000, ketergantungan Indonesia terhadap permintaan domestik tercatat sebesar 90,3\% dan pada tahun 2010 menjadi 91,4\%. Angka ini sejalan dengan peningkatan konsumsi domestik Indonesia yang menjadi sumber pertumbuhan ekonomi. Sementara keterkaitan Indonesia dengan perdagangan eksternal relatif semakin menurun terutama untuk barang-barang yang berbentuk final demand. Produkproduk berbentuk final demand umumnya digunakan di negara Asia Tenggara dan besarannya semakin meningkat dibandingkan tahun 2000 (dari semula 1,2\% menjadi 1,4\%), sementara 
hasil perhitungan menunjukkan perdagangan internasional yang dilakukan Indonesia dengan negara lainnya cenderung berupa barang intermediate.

Sebagai pembanding, dalam tabel yang sama, China menunjukkan pola perdagangan sebagai supplier utama. Sekalipun peran domestic demand terhadap value added China masih relatif tinggi yaitu $87,6 \%$ tahun 2010 , tetapi besaran itu semakin menurun apabila dibandingkan dengan tahun 2000. Peran permintaan domestik yang semakin menurun digantikan dengan perdagangan final demand dari negara lain. Pertumbuhan ekspor final demand yang terbesar adalah antara China dengan negara maju yaitu AS. Oleh karena itu, setiap perubahan final demand di negara tersebut akan berdampak yang besar terhadap nilai tambah China. Perhitungan ini memberikan konfirmasi bahwa sebagai supplier utama, China tidak hanya bergerak di bidang barang intermediate tetapi juga barang-barang final.

Namun demikian, ekonomi yang lebih mengarah pada domestik bukan tanpa risiko. Pengembangan sektor industri untuk kebutuhan domestik yang kuat tetap menjadi modal utama. Dalam kondisi persaingan perdagangan internasional yang semakin ketat, aliran barang murah dari luar negeri dapat masuk dengan mudah dan menyerang industri domestik. Oleh karena itu, apabila daya saing produksi domestik kalah dengan negara lain, yang terjadi adalah banjirnya impor barang khususnya barang konsumsi. Selain itu, pilihan strategi yang terlalu berorientasi domestik kurang dapat memanfaatkan momentum pertumbuhan ekonomi dunia pada saat terjadi recovery dan pertumbuhan tinggi.

\subsection{AIO Sektoral : Backward dan Forward Linkages}

Bagian penting lain yang menjadi fokus analisa adalah seberapa besar sektor-sektor di Indonesia yang memiliki keterkaitan yang kuat dengan rantai produksi dunia. Data agregat tidak dapat menangkap keragaman (heterogeneity data). Dengan menggunakan metode RAS, dilakukan iterasi untuk mendapatkan angka pada sisi sektoral. Hasil perhitungan BL dan FL pada sisi sektoral, dapat dilihat pada Tabel 15 dan 16.

\begin{tabular}{|c|c|c|}
\hline \multicolumn{3}{|c|}{$\begin{array}{c}\text { Tabel } 15 \\
\text { Backward Linkages Sektor Utama Indonesia }\end{array}$} \\
\hline Backward Linkages - Sector & 2000 & 2010 \\
\hline Trade and transport & 3,74 & 4,31 \\
\hline Crude petroleum and natural gas & 3,50 & 4,28 \\
\hline Services & 2,77 & 3,16 \\
\hline Other mining & 2,12 & 2,40 \\
\hline Food, beverage and tobacco & 2,02 & 2,21 \\
\hline Chemical products & 1,95 & 2,12 \\
\hline Other agricultural products & 1,74 & 1,90 \\
\hline Transport equipment & 1,73 & 1,89 \\
\hline Pulp, paper and printing & 1,59 & 1,72 \\
\hline Metal products & 1,58 & 1,70 \\
\hline
\end{tabular}




\begin{tabular}{l|r|r}
\multicolumn{3}{c}{ Tabel 16 } \\
Forward Linkages Sektor Utama Indonesia \\
Forward Linkages -Sector & $\mathbf{2 0 0 0}$ & $\mathbf{2 0 1 0}$ \\
Textile, leather, and the products thereof & 2,07 & 2,13 \\
\hline Timber and wooden products & 1,97 & 2,08 \\
\hline Electricity, gas, and water supply & 1,95 & 2,08 \\
\hline Food, beverage and tobacco & 1,97 & 2,07 \\
\hline Construction & 1,97 & 2,05 \\
\hline Metal products & 2,00 & 2,04 \\
\hline Other manufacturing products & 2,03 & 2,02 \\
\hline Transport equipment & 1,94 & 2,01 \\
\hline Livestock and poultry & 1,85 & 1,98 \\
\hline Machinery & 2,01 & 1,96
\end{tabular}

Hasil perhitungan di atas menunjukkan bahwa pada tahun 2010 sektor yang memiliki backward linkages yang terkuat adalah sektor Trade and Transport $(4,31)$ dan Crude petroleum and Natural Gas $(4,28)$. Kedua sektor ini, juga mengalami peningkatan kebutuhan import dibandingkan tahun 2000. Di sisi lain, sektor yang memiliki forward linkages (ekspor barang intermediate) yang terbesar pada tahun 2010 adalah sektor textile, leather, and the products thereof $(2,13)$ diikuti dengan Timber and wooden products $(2,08)$.

Hal yang menarik dari tabel forward linkages di Tabel 16 adalah sektor mesin. Pada tahun 2000, sektor ini merupakan sektor utama yang memiliki forward linkages yang terbesar, tetapi pada tahun 2010, sektor ini memiliki keterkaitan yang semakin kecil. Hal ini diduga karena barang intermediate berupa mesin-mesin digunakan untuk kebutuhan dalam negeri Indonesia dan bukan diekspor. Hal ini sejalan dengan kegiatan investasi Indonesia yang meningkat akhirakhir ini dan membutuhkan barang modal yang besar.

Sektor yang memiliki BL yang terbesar, yaitu trade and transport, memiliki keterkaitan import yang terbesar dengan China, sementara FL terbesar untuk sektor ini (ekspor barang intermediate) dengan negara AS. Sementara sektor textile, leather, and the products thereof memiliki import content yang terbesar dengan Malaysia, sementara hasil dari sektor ini memiliki FL dengan negara Korea dan Amerika Serikat.

Sebagai pembanding untuk hasil perhitungan indeks FL dan BL di atas, kita juga dapat menggunakan indeks Grubel-Lloyd (GL) untuk melihat karakteristik perdagangan internasional suatu negara. Indeks Grubel-Lloyd dikenalkan tahun 1975. Rumusan indeks tersebut adalah membandingkan ekspor dan impor untuk jenis barang (kelompok barang) yang sama, seperti terlihat dalam rumus berikut ini:

$$
G L_{\text {sector } i}=1-\left\{\frac{\text { ekspor }_{\text {sector i }}-\text { impor }_{\text {sector i }} \mid}{\text { ekspor }_{\text {sector i }}+\text { impor }_{\text {sector i }}}\right\}
$$


Jika suatu negara melakukan ekspor dan impor untuk barang (kelompok barang) yang sama dengan jumlah yang sama, maka indeks GL sama dengan 1. Sementara apabila negara hanya ekspor atau hanya impor untuk komoditi tertentu maka indeks GL sebesar 0. Dengan demikian variasi indeks berkisar antara 0 (menunjukkan inter-industry trade murni) sampai dengan 1 (intra-industry trade).

Kecenderungan indeks GL yang mendekati 1 mempunyai indikasi adanya kaitan yang relatif kuat dalam rantai produksi barang secara global atau secara bilateral, sehingga lebih sensitif terhadap siklus ekonomi dunia. Negara dikawasan regional dengan indeks paling tinggi di tahun 2010 adalah Singapura (0,8), serta Thailand dan Malaysia (sekitar 0,7). Sementara Indonesia dan China relatif memiliki indeks GL relatif rendah sekitar 0,5 (Grafik 7). Berdasarkan pengamatan di grafik yang sama tersebut, tampak bahwa sebagian besar negara mengalami kecenderungan peningkatan indeks dari tahun 2000 ke 2010. Hal ini menambah hipotesa bahwa semakin banyak negara meningkatkan orientasi perdagangan internasional. Meskipun belum sepenuhnya diuji secara lebih kuat, negara dengan kecenderungan indeks tinggi dan rendah tersebut sejalan dengan indikator derajat keterbukaan ekonomi.

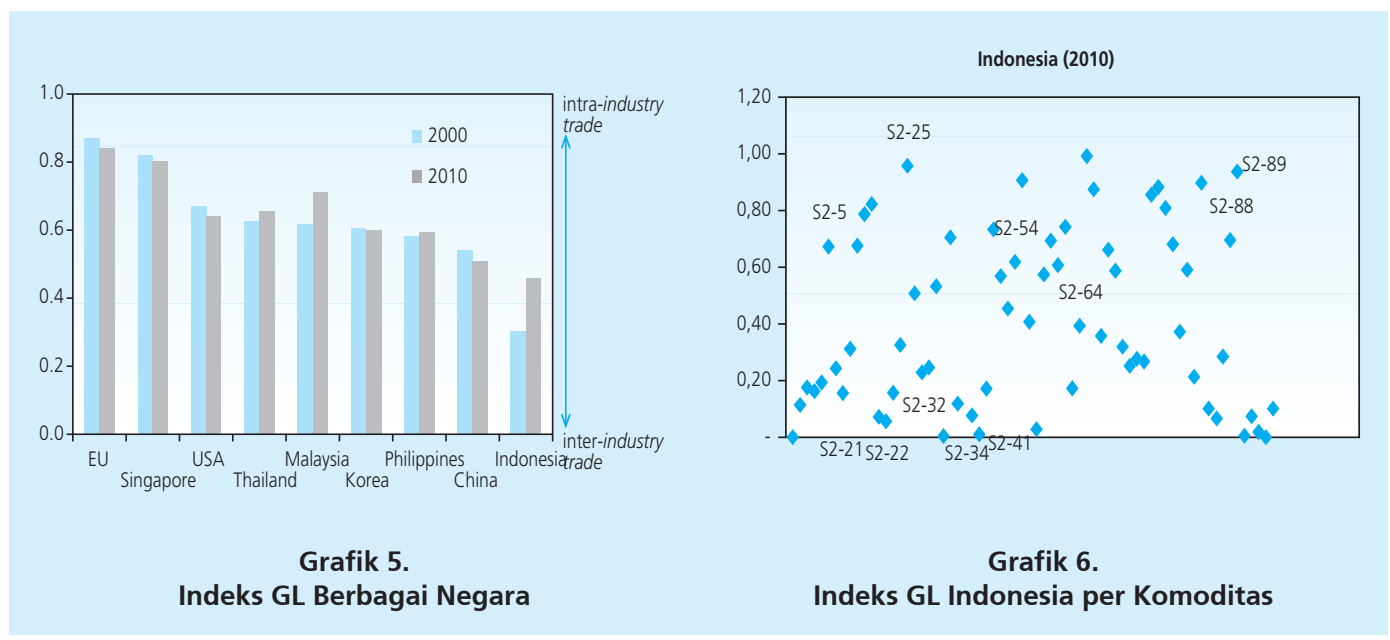

Untuk Indonesia, sebaran indeks per komoditas terlihat lebih banyak mengumpul pada area dibawah 0,5 (Grafik 6). Komoditas yang memiliki indeks di atas rata-rata adalah seperti bubur kertas, perlengkapan mesin, produk tekstil dan benang. Perdagangan internasional Indonesia yang bersifat barang primer atau bahan mentah seperti hewan, CPO, batubara dan migas cenderung mempunyai indeks mendekati 0 .

Aplikasi indeks GL juga dapat diterapkan untuk melihat pola perdagangan bilateral. Berdasarkan data bilateral perdagangan Indonesia, partner dagang Indonesia seperti Thailand, Malaysia, dan Korea memiliki indeks yang relatif tinggi (Grafik 7). Pola sebaran komoditas per negara partner dagang dan dunia terlihat di grafik 8 . 


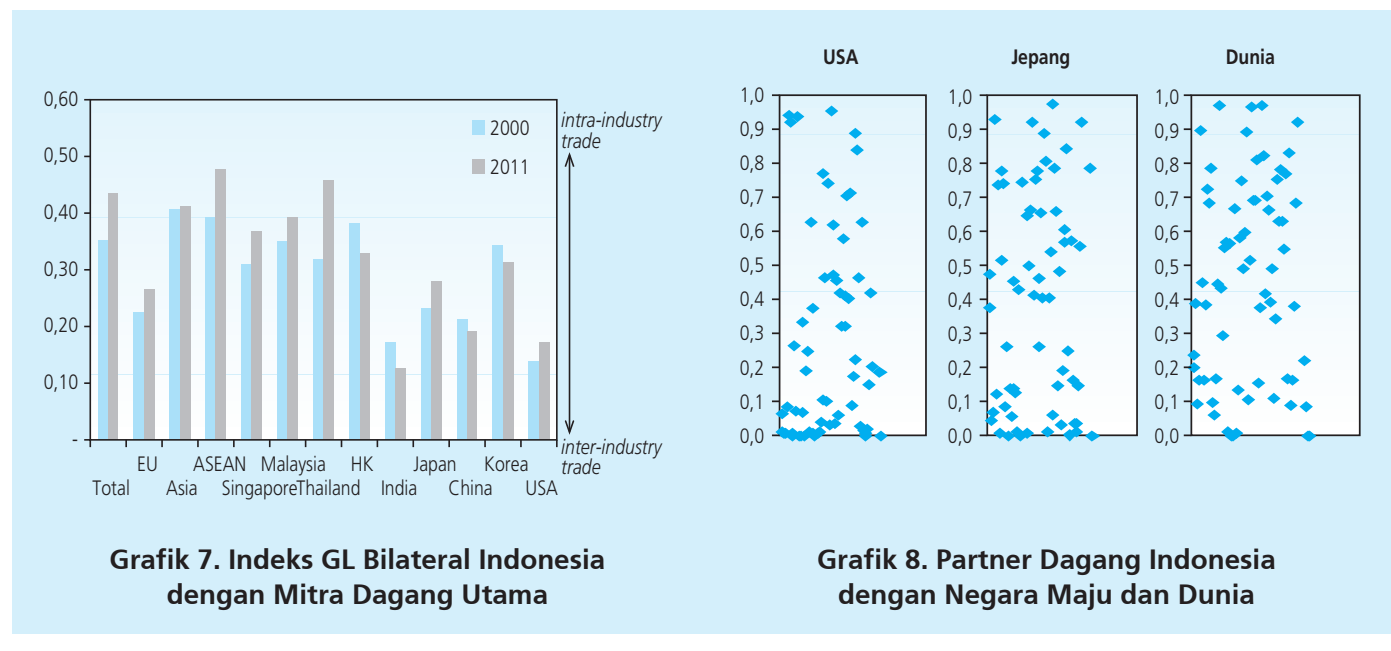

\subsection{Simulasi Dampak Penurunan PDB AS}

Pada tahun 1980, AS merupakan negara yang sangat dominan dengan kontribusi perdagangan dunia mencapai $12 \%$, disusul oleh Jepang 6,7\% $\%^{5}$. Seiring dengan pertumbuhan China yang impresif dalam dekade terakhir dan menjadi penggerak ekonomi kawasan Asia, kontribusi perdagangan AS di pasar dunia sedikit demi sedikit dapat diimbangi. Kontribusi perdagangan China pada tahun 2011 menjadi sebesar 10,2\% relatif berimbang dengan data perdagangan AS sebesar 10,4\%, sementara peran Jepang justru menurun menjadi 4,7\% (data IMF-WEO April 2012).

Penurunan ekonomi dunia tahun 2009 yang dipicu oleh Amerika Serikat (AS), menjadi salah satu sebab perlambatan ekonomi di kawasan lainnya. Krisis yang berlangsung tersebut sempat dikhawatirkan berdampak signifikan kepada negara berkembang, mengingat kontribusi perekonomian AS dalam perdagangan dunia yang sangat besar. Pada tahun 2009, ekonomi dunia turun menjadi 0,6\% terutama disebabkan oleh penurunan pertumbuhan yang terjadi di negara maju sebesar 3,6\%. Sementara negara berkembang dunia, khususnya negara berkembang Asia masih cukup kuat dan mampu tetap tumbuh 7,1\%. Masih kuatnya pertumbuhan ekonomi Asia menguatkan berbagai dugaan dan pertanyaan apakah ekonomi Asia sudah mengalami decoupling dengan ekonomi AS. Terkait dengan ini, paper ini memberikan simulasi kuantitatif untuk menjawab

Dengan menggunakan tabel AIO tahun 2010 yang telah diupdate, bagian ini akan melakukan simulasi penurunan PDB AS sebesar 1\% dan dampaknya terhadap PDB negara kawasan yang ada dalam Asian IO. Dalam simulasi ini akan dibandingkan dampak terhadap negara di seluruh kawasan serta dampak antar waktu, yaitu dampak tahun 2010 dibandingkan dengan dampak pada tahun 2000.

5 Kontribusi perdagangan dunia dihitung dari total ekspor plus impor suatu negara dibagi dengan total ekspor plus impor dunia. 


\begin{tabular}{|c|c|c|c|c|c|}
\hline \multicolumn{6}{|c|}{$\begin{array}{c}\text { Tabel } 17 \\
\text { Dampak Perlambatan PDB AS terhadap PDB Negara Kawasan (\%) }\end{array}$} \\
\hline & \multicolumn{2}{|c|}{ Th. 2000} & \multicolumn{2}{|c|}{ Th. 2010} & \multirow{2}{*}{$\begin{array}{l}(4) /(2) \\
\text { Rasio }\end{array}$} \\
\hline & $\begin{array}{l}\text { Dampak } \\
\text { Langsung }\end{array}$ & $\begin{array}{l}\text { Dampak } \\
\text { Total }\end{array}$ & Dampak Langsung & Dampak Total & \\
\hline Negara & (1) & $(2)$ & (3) & (4) & (5) \\
\hline Indonesia & $-0,054$ & $-0,097$ & $-0,018$ & $-0,046$ & 0,48 \\
\hline Malaysia & $-0,121$ & $-0,180$ & $-0,061$ & $-0,131$ & 0,73 \\
\hline Filipina & $-0,098$ & $-0,168$ & $-0,068$ & $-0,162$ & 0,96 \\
\hline Singapura & $-0,092$ & $-0,136$ & $-0,038$ & $-0,090$ & 0,66 \\
\hline Thailand & $-0,074$ & $-0,125$ & $-0,032$ & $-0,101$ & 0,81 \\
\hline Cina & $-0,056$ & $-0,102$ & $-0,025$ & $-0,128$ & 1,25 \\
\hline Taiwan & $-0,077$ & $-0,131$ & $-0,042$ & $-0,136$ & 1,04 \\
\hline Korea & $-0,051$ & $-0,092$ & $-0,026$ & $-0,082$ & 0,89 \\
\hline Jepang & $-0,029$ & $-0,057$ & $-0,014$ & $-0,033$ & 0,58 \\
\hline
\end{tabular}

Dari Tabel 17 terlihat bahwa dampak perlambatan AS terhadap negara dalam kawasan tersebut secara keseluruhan mengalami penurunan pada tahun 2010 dibandingkan dengan tahun 2000 kecuali dampaknya pada China dan Taiwan. Dampak perlambatan PDB AS terhadap Indonesia mengalami penurunan hampir 50\%, dalam simulasi tersebut jika PDB AS melambat 1\%, maka dampaknya pada PDB Indonesia akan melambat 0,046\% tahun 2010, menurun dibandingkan dengan dampak pada tahun 2000 yang mencapai 0,097\%. Hal ini sejalan dengan penurunan pangsa ekspor non migas Indonesia ke AS yang menurun dari 16,8\% pada tahun 2000 menjadi 9,6\% pada tahun 2011.

Sedangkan dampak perlambatan AS terhadap negara Taiwan hampir tidak berubah. Dampak perlambatan PDB AS terhadap Taiwan menunjukkan dampak konstan, dimana dalam simulasi tersebut jika PDB AS melambat 1\%, maka dampaknya pada PDB Taiwan akan melambat 0,136\% tahun 2010, hampir tidak berubah dibandingkan dengan dampak pada tahun 2000 yang menunjukkan perlambatan sekitar 0,131\%. Hal ini bisa dipahami terkait dengan hubungan tradisional yang harmonis antara Taiwan dengan AS selama ini. Dari data perdagangan bilateral antara kedua negara tersebut terlihat bahwa AS adalah tujuan ekspor terbesar kedua bagi Taiwan yaitu sekitar 12\% pangsa ekspor Taiwan ditujukan ke AS.

Sementara itu dampak perlambatan AS terhadap negara China mengalami peningkatan yang signifikan. Dampak perubahan PDB AS terhadap China tahun 2010 mengalami peningkatan hampir $125 \%$ dibandingkan dengan tahun 2000, dalam simulasi tersebut jika PDB AS melambat $1 \%$, maka dampaknya pada PDB China akan melambat 0,128\% tahun 2010, meningkat 
dibandingkan dengan dampak pada tahun 2000 yang mencapai 0,102\%. Hal ini sejalan dengan fakta bahwa AS adalah tujuan pertama terbesar ekspor China, pangsa ekspor China ke AS mencapai 17,7\% dari total ekspor China pada tahun 2010. Perkembangan yang pesat keterkaitan China dengan AS tersebut merupakan dampak dari masuknya China dalam WTO tahun 2001 dan dihapuskannya multi fiber arrangement oleh AS tahun 2005. Dari hasil simulasi ini semakin menunjukkan China memiliki ketergantungan yang semakin tinggi terhadap kinerja perekonomian AS.

Hasil simulasi dampak penurunan PDB AS terhadap sektor perekonomian Indonesia dapat dilihat pada Tabel 18. Dalam tabel tersebut hanya ditampilkan lima sektor terbesar dampak dari penurunan PDB AS 1\%. Dampak terbesar akan dirasakan oleh sektor tekstil, kulit dan turunannya. Jika PDB AS melambat 1\%, maka dampaknya pada sektor tekstil, kulit dan turunannya akan melambat 0,0062\%. Hal ini didukung oleh data tujuan ekspor tekstil Indonesia ke AS pada tahun 2012 (Januari-Mei) yang pangsanya mencapai 33\% dari total ekspor tekstil Indonesia.

\begin{tabular}{|l|c|}
\hline \multicolumn{2}{|c|}{ Tabel 18 } \\
Dampak Penurunan PDB AS terhadap PDB Sektoral Indonesia (\%) \\
\hline \multicolumn{1}{|c|}{ Sektor } & $\begin{array}{c}\mathbf{2 0 1 0} \\
\text { Dampak Total }\end{array}$ \\
\hline Tekstil, Kulit dan Produk lainnya & $-0,0062$ \\
Produk Karet & $-0,0046$ \\
Mesin & $-0,0040$ \\
Kayu dan Produk Kayu & $-0,0034$ \\
Kehutanan & $-0,0028$ \\
\hline
\end{tabular}

\subsection{Simulasi Dampak Penurunan Ekspor Kawasan ke EU}

Bagian ini mengulas dampak penurunan ekspor kawasan Asia dan AS ke Eropa (EU). Besaran penurunan eskspor yang disimulasikan adalah 1\% dari PDB negara kawasan yang ada dalam tabel Asian IO. Hasil simulasi antara tahun 2000 dan 2010 akan dibandingkan dan khusus untuk Indonesia, analisa mencakup sampai pada dampak sektoral terbesar yang terpengaruh dari perlambatan ekspor ke EU 1\% tersebut.

Dari Tabel 19 terlihat bahwa dampak penurunan ekspor ke EU terhadap negara dalam kawasan tersebut secara sekilas menunjukkan dampak yang variatif pada tahun 2010 dibandingkan dengan tahun 2000. Dibandingkan tahun 2000, dampak penurunan ekspor ke EU bagi Indonesia pada tahun 2010, mengalami penurunan hampir 15\%. Penurunan ekspor 


\begin{tabular}{|c|c|c|c|c|c|}
\hline \multicolumn{6}{|c|}{$\begin{array}{c}\text { Tabel } 19 \\
\text { Dampak Penurunan Ekspor ke EU terhadap PDB Negara Kawasan (\%) }\end{array}$} \\
\hline & \multicolumn{2}{|c|}{ Th. 2000} & \multicolumn{2}{|c|}{ Th. 2010} & \multirow{2}{*}{$\begin{array}{l}(4) /(2) \\
\text { Rasio }\end{array}$} \\
\hline & $\begin{array}{l}\text { Dampak } \\
\text { Langsung }\end{array}$ & $\begin{array}{c}\text { Dampak } \\
\text { Total }\end{array}$ & $\begin{array}{l}\text { Dampak } \\
\text { Langsung }\end{array}$ & $\begin{array}{l}\text { Dampak } \\
\text { Total }\end{array}$ & \\
\hline Negara & (1) & (2) & (3) & (4) & (5) \\
\hline Indonesia & $-0,048$ & $-0,086$ & $-0,037$ & $-0,073$ & 0,85 \\
\hline Malaysia & $-0,098$ & $-0,151$ & $-0,065$ & $-0,121$ & 0,80 \\
\hline Filipina & $-0,067$ & $-0,115$ & $-0,039$ & $-0,114$ & 0,99 \\
\hline Singapura & $-0,083$ & $-0,124$ & $-0,056$ & $-0,127$ & 1,02 \\
\hline Thailand & $-0,050$ & $-0,085$ & $-0,035$ & $-0,119$ & 1,39 \\
\hline Cina & $-0,030$ & $-0,057$ & $-0,120$ & $-0,571$ & 9,99 \\
\hline Taiwan & $-0,058$ & $-0,099$ & $-0,062$ & $-0,238$ & 2,40 \\
\hline Korea & $-0,040$ & $-0,072$ & $-0,047$ & $-0,164$ & 2,28 \\
\hline Jepang & $-0,017$ & $-0,033$ & $-0,013$ & $-0,039$ & 1,18 \\
\hline U.S.A. & $-0,016$ & $-0,031$ & $-0,015$ & $-0,041$ & 1,35 \\
\hline
\end{tabular}

ke EU sebesar $1 \%$ dari negara kawasan, akan berdampak pada penurunan PDB Indonesia sebesar 0,073\% untuk tahun 2010, sementara untuk tahun 2000 sebesar 0,086\%. Hal ini sejalan dengan penurunan pangsa ekspor non migas Indonesia ke EU dari 18,0\% pada tahun 2000 menjadi 12,4\% pada tahun 2011.

Sementara itu dampak penurunan ekspor ke EU yang terbesar dirasakan oleh China. Dampak perubahan kinerja perekonomian EU terhadap China tahun 2010 mengalami peningkatan hampir 10 kali dibandingkan dengan tahun 2000. Dalam simulasi tersebut jika ekspor ke EU melambat 1\%, maka dampaknya pada PDB China akan melambat 0,571\% tahun 2010, meningkat dibandingkan dengan dampak pada tahun 2000 yang mencapai 0,057\%. Hal ini sejalan dengan peningkatan pangsa ekspor China ke EU yang meningkat dari 16\% pada tahun 2000 menjadi 24\% pada tahun 2010. Perkembangan yang pesat keterkaitan China dengan EU tersebut ditengarai diantaranya dampak dari masuknya China dalam WTO tahun 2001. Hasil simulasi ini semakin menunjukkan China memiliki ketergantungan yang semakin tinggi terhadap kinerja perekonomian EU. Karena itu tambahan bantuan China ke EU untuk program pemulihan EU melalui IMF baru-baru ini terasa sangat relevan tidak hanya bagi EU tetapi juga bagi China.

Hasil simulasi dampak penurunan ekonomi EU terhadap sektor perekonomian Indonesia dapat dilihat pada Tabel 20. Dalam tabel tersebut hanya ditampilkan lima sektor terbesar dampak dari penurunan ekspor ke EU 1\%. Dampak terbesar akan dirasakan oleh sektor perdagangan dan 
transportasi. Jika ekspor ke EU melambat 1\%, maka sektor perdagangan dan transportasiakan melambat sebesar 0,011\%.

Sebagai tambahan informasi, berdasarkan data statistik ekspor non migas Indonesia, kurang lebih 50\% dari ekspor ke EU ditujukan ke tiga negara utama yaitu Belanda, Jerman, dan Itali. Berdasarkan data 2009-2011, pangsa masing-masing negara tersebut terhadap total ekspor ke EU adalah 21,2\%, 15,9\%, dan 13,1\%.

\begin{tabular}{|l|c|}
\hline \multicolumn{2}{|c|}{ Tabel 20 Dampak Penurunan Ekspor ke EU terhadap } \\
PDB Sektoral Indonesia (\%), 2010 \\
\hline \multicolumn{1}{|c|}{ Sektor } & Dampak Total \\
\hline Perdagangan dan transportasi & $-0,01070$ \\
Tekstil, kulit dan produk lainnya & $-0,00672$ \\
Minyak mentah dan gas alam & $-0,00670$ \\
Makanan, minuman, dan tembakau & $-0,00667$ \\
Pulp, kertas dan percetakana & $-0,00327$ \\
\hline
\end{tabular}

\subsection{Simulasi Dampak Penurunan PDB China}

Bagian ini mengulas dampak penurunan PDB China sebesar 1\%, terhadap PDB negara kawasan yang ada dalam Asian IO. Tabel 21 menunjukkan penurunan China memberikan dampak yang lebih besar untuk tahun 2010 dibandingkan dengan tahun 2000, dengan peningkatan terbesar dialami oleh AS.

Dampak penurunan PDB China terhadap Indonesia mengalami peningkatan hampir 4 kali; penurunan PDB China sebesar 1\% menyebabkan PDB Indonesia menurun 0,140\% tahun 2010, dan 0,034\% untuk tahun 2000. Ini sejalan dengan peningkatan pangsa ekspor non migas Indonesia ke China dari 3,6\% pada tahun 2000 menjadi 13,3\% pada tahun 2011. Dengan demikian tren penurunan perekonomian China, patut diwaspadai oleh Indonesia.

Sementara itu dampak penurunan China terhadap AS mengalami peningkatan terbesar dibandingkan negara lain. Dampak bagi AS untuk tahun 2010 lebih tinggi 7 kali dibandingkan tahun 2000. Untuk setiap 1\% penurunan PDB China, PDB AS akan menurun 0,030\% untuk tahun 2010, dan 0,004\% untuk 2000. Hal ini sejalan dengan peningkatan ekspor AS ke China yang terus meningkat sebesar 542\%; dari USD16,2 miliar pada tahun 2000 menjadi USD103,9 miliar pada tahun 2011. Ekspor AS ke rest of the world dalam periode yang sama mengalami peningkatan sebesar 80\%. China merupakan tujuan ekspor ketiga terbesar bagi AS, setelah Kanada dan Meksiko. Produk utama yang diekspor ke China adalah produk pertanian dan 


\begin{tabular}{|c|c|c|c|c|c|}
\hline \multicolumn{6}{|c|}{$\begin{array}{c}\text { Tabel } 21 \\
\text { Dampak Penurunan PDB China terhadap PDB Negara Kawasan (\%) }\end{array}$} \\
\hline & \multicolumn{2}{|c|}{ Th. 2000} & \multicolumn{2}{|c|}{ Th. 2010} & \multirow{2}{*}{$\begin{array}{l}(4) /(2) \\
\text { Rasio }\end{array}$} \\
\hline & $\begin{array}{l}\text { Dampak } \\
\text { Langsung }\end{array}$ & $\begin{array}{l}\text { Dampak } \\
\text { Total }\end{array}$ & $\begin{array}{l}\text { Dampak } \\
\text { Langsung }\end{array}$ & $\begin{array}{l}\text { Dampak } \\
\text { Total }\end{array}$ & \\
\hline Negara & (1) & (2) & (3) & (4) & (5) \\
\hline Indonesia & $-0,020$ & $-0,034$ & $-0,064$ & $-0,140$ & 4,12 \\
\hline Malaysia & $-0,035$ & $-0,055$ & $-0,102$ & $-0,182$ & 3,34 \\
\hline Filipina & $-0,014$ & $-0,024$ & $-0,072$ & $-0,148$ & 6,16 \\
\hline Singapura & $-0,031$ & $-0,052$ & $-0,063$ & $-0,102$ & 1,95 \\
\hline Thailand & $-0,020$ & $-0,033$ & $-0,046$ & $-0,093$ & 2,79 \\
\hline Taiwan & $-0,058$ & $-0,089$ & $-0,228$ & $-0,416$ & 4,66 \\
\hline Korea & $-0,034$ & $-0,059$ & $-0,095$ & $-0,184$ & 3,14 \\
\hline Jepang & $-0,008$ & $-0,015$ & $-0,031$ & $-0,072$ & 4,76 \\
\hline U.S.A. & $-0,002$ & $-0,004$ & $-0,013$ & $-0,030$ & 7,03 \\
\hline
\end{tabular}

produk teknologi tinggi. Hasil simulasi ini menunjukkan bahwa perekonomian AS dan China memiliki peningkatan saling ketergantungan satu sama lain.

Hasil simulasi dampak sektoral dari penurunan PDB China terhadap perekonomian Indonesia dapat dilihat pada Tabel 22. Dampak terbesar dirasakan oleh sektor Perdagangan dan Transportasi. Jika PDB China menurun 1\%, maka sektor Perdagangan dan Transportasi akan menurun sebesar 0,079\%.

\begin{tabular}{|c|c|}
\hline \multicolumn{2}{|c|}{$\begin{array}{c}\text { Tabel } 22 \text { Dampak Penurunan GDP China } \\
\text { terhadap PDB Sektoral Indonesia (\%) }\end{array}$} \\
\hline \multicolumn{2}{|c|}{ Th. 2010} \\
\hline Sektor & DampakTotal \\
\hline Perdagangan dan transportasi & $-0,07886$ \\
\hline Makanan, minuman dan tembakau & $-0,07870$ \\
\hline Konstruksi & $-0,05895$ \\
\hline Minyak mentah dan gas alam & $-0,03845$ \\
\hline Alat transportasi & $-0,02632$ \\
\hline
\end{tabular}




\subsection{Robustness Check}

Setelah melakukan perhitungan dan analisa dengan menggunakan AIO Tahun 2010, selanjutnya dilakukan analisa robustness check. Selain membandingkan dengan hasil temuan studi lainnya, bagian ini juga akan menunjukkan konsistensi koefisien BL dengan iterasi RAS yang dilakukan.

Pertama, uji robustness di dalam model. Menguji apakah iterasi RAS yang digunakan cukup valid atau tidak, dilakukan dengan membandingkan koefisien BL pada setiap iterasi tertentu. Hasil pengujian menunjukkan bahwa backward linkages untuk setiap negara dapat dikatakan telah cukup stabil dan konsisten. Hal tersebut dapat ditunjukkan pada tabel 25 sebagai berikut:

\begin{tabular}{|c|c|c|c|c|c|c|c|c|}
\hline \multicolumn{9}{|c|}{$\begin{array}{c}\text { Tabel } 23 \\
\text { Backward Linkages dan Jumlah Iterasi RAS }\end{array}$} \\
\hline \multirow{2}{*}{$\begin{array}{c}\text { Backward Linkage } \\
\text { Negara }\end{array}$} & \multicolumn{8}{|c|}{ Jumlah Iterasi } \\
\hline & 5 & 10 & 15 & 30 & 50 & 100 & 150 & 200 \\
\hline Indonesia & 1,87 & 1,87 & 1,87 & 1,87 & 1,87 & 1,87 & 1,87 & 1,87 \\
\hline Malaysia & 1,46 & 1,47 & 1,47 & 1,47 & 1,47 & 1,47 & 1,47 & 1,47 \\
\hline Filipina & 1,69 & 1,69 & 1,69 & 1,69 & 1,69 & 1,69 & 1,69 & 1,69 \\
\hline Singapura & 1,43 & 1,43 & 1,43 & 1,43 & 1,43 & 1,43 & 1,43 & 1,43 \\
\hline Thailand & 2,15 & 2,17 & 2,17 & 2,17 & 2,17 & 2,17 & 2,17 & 2,17 \\
\hline Cina & 5,14 & 5,18 & 5,20 & 5,20 & 5,20 & 5,20 & 5,20 & 5,20 \\
\hline Taiwan & 2,14 & 2,16 & 2,16 & 2,17 & 2,17 & 2,17 & 2,17 & 2,17 \\
\hline Korea & 2,36 & 2,38 & 2,38 & 2,39 & 2,38 & 2,38 & 2,38 & 2,38 \\
\hline Jepang & 1,82 & 1,82 & 1,82 & 1,81 & 1,81 & 1,81 & 1,81 & 1,81 \\
\hline U.S.A. & 2,24 & 2,28 & 2,30 & 2,32 & 2,32 & 2,32 & 2,32 & 2,32 \\
\hline
\end{tabular}

Kedua, uji robustness dengan membandingkan temuan studi ini dengan penelitian lain. Hasil estimasi staf IMF dengan menggunakan AIO 1995 dan 2010 menunjukkan peta BL yang serupa, dimana saat ini semua negara AIO memiliki keterkaitan yang sangat kuat dengan China, sementara keterkaitan perdagangan dengan negara Jepang melemah.

Studi lainnya yang dapat menjadi uji robustness adalah hasil estimasi IMF terkait sensitivitas ekspor Asia terhadap China. Studi ini menunjukkan bahwa ekspor komoditi Indonesia memiliki sensitivitas yang lebih tinggi dibandingkan dengan ekspor manufaktur (yang umumnya merupakan barang final), lihat Tabel 25. Hasil studi IMF ini sejalan dengan paper ini bahwa umumnya ekspor produk Indonesia memiliki kontribusi terhadap value added yang lebih kecil. 
Lebih jauh, ekspor komoditas Indonesia cenderung digunakan untuk memenuhi kebutuhan domestik China, dan bukan digunakan untuk kegiatan ekspor.

Dengan menggunakan kedua uji robustness di atas, hasil updating Asian IO 2010 dapat dianggap cukup valid dalam menggambarkan struktur perdagangan ASIA, AS, dan EU pada tahun tersebut.

Tabel 24

Peta Keterkaitan Perdagangan antar Negara

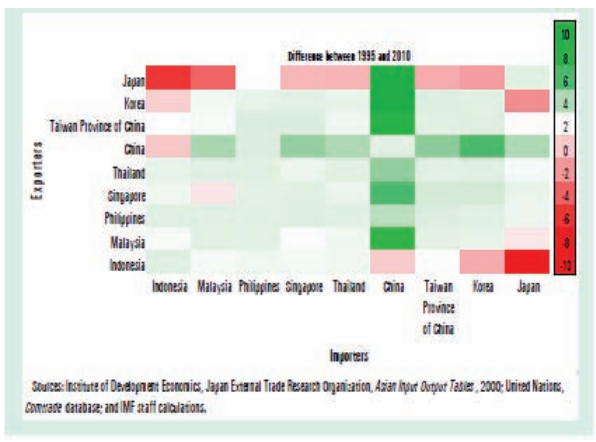

Tabel 25

Determinan Ekspor Asia ke China

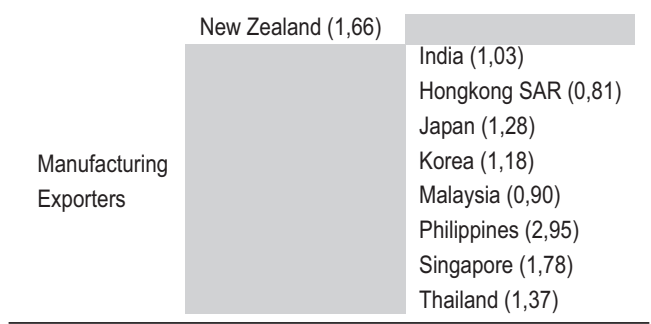

Source : IMF Staff Estimates

${ }^{1}$ Numbers in parentheses denote elasticity of exports to China at 5 percent level of significance. Shaded areas indicate no significance at 5 percent level.

\section{KESIMPULAN}

Paper ini menggunakan model Asian Input Output untuk menganalisa dampak suatu gejolak yang berasal dari satu negara terhadap negara lainnya, yang ditransmisikan melalui perdagangan internasional. Hasil perhitungan menunjukkan bahwa dampak pelemahan ekonomi AS dan EU terhadap negara lain mempunyai kecenderungan yang mengecil selang periode tahun 2000 dan 2010. Sementara dampak pelemahan ekonomi China cenderung membesar pada semua negara.

Bagi Indonesia, perlambatan ekonomi China berdampak relatif lebih besar dibandingkan perlambatan dari AS maupun EU. Hasil simulasi dampak langsung penurunan PDB sebesar $1 \%$ dari negara AS, EU dan China terhadap ekonomi Indonesia masing-masing sebesar -0,018\%, $-0,037 \%$ dan $-0,064 \%$. Sementara untuk dampak total masing-masing sebesar $-0,046 \%$, $-0,073 \%$, dan $-0,140 \%$.

Secara umum, dampak penurunan ekonomi negara maju terhadap Indonesia relatif rendah dibandingkan dengan yang dirasakan negara lain di ASEAN. Ini sejalan dengan jenis ekspor Indonesia yang lebih bersifat barang komoditas dengan nilai tambah yang rendah. Selain itu keterkaitan intra-trade industry komoditas ekspor Indonesia relatif rendah, sementara sumber pertumbuhan ekonomi Indonesia dominan masih bersumber dari permintaan domestik.

Hasil di atas memiliki beberapa implikasi penting bagi Indonesia. Pertama, potensi dampak pelemahan ekonomi dunia ke Indonesia perlu dicermati ketika terdapat pelemahan ekonomi 
di negara maju yang berkepanjangan, disertai dengan tanda-tanda perlambatan permintaan domestik China. Kedua, meskipun hasil simulasi menunjukkan dampak pelemahan ekonomi utama dunia ke Indonesia yang relatif kecil, bukan berarti ekonomi Indonesia sepenuhnya dipandang baik. Tipikal ekspor berbasis komoditas dan masih rendahnya indikator IIT menunjukkan bahwa peran Indonesia dalam mata rantai perdagangan dunia masih terbatas. Untuk itu, diversifikasi produk ekspor yang berorientasi pada produk yang mempunyai nilai tambah tinggi perlu di tingkatkan.

Terkait penelitian lebih lanjut, perlu digarisbawahi bahwa model IO merupakan model statis dan belum memasukkan fungsi perilaku. Diharapkan penelitian lanjutan dapat menggunakan model Computable General Equilibrium (CGE) yang dapat menginternalisir perilaku dari 10 negara yang menjadi subjek kajian. 


\section{DAFTAR PUSTAKA}

Bank Indonesia. Buletin Ekspor Impor Indonesia. Departemen Statistik Ekonomi Moneter, Bank Indonesia, Berbagai Edisi

Buetre dan Esfahani (2000). Updating an Input Output Table for Use in Policy Analysis. The Australian Journal of Agricultural and Resource Economics, 44:4, pp. 573-603.

Capilit, E (2009). RAS Method. Paper prepared for presentation at the 2nd Data Review Workshop, ADB, 7-12 December 2009

Christ, F. Carl, 1955, A Review of Input-Output Analysis, Volume Title: Input-Output Analysis: An Appraisal, Princeton University Press, http://www.nber.org/books/unkn55-2

Ibrahim, et al. (2010). Dampak ACFTA terhadap Perdagangan Internasional Indonesia. Direktorat Riset Ekonomi dan Kebijakan Moneter Bank Indonesia

International Monetary Fund (2012). Regional Economic Outlook: Asia and Pacific Managing Spillovers and Advancing Economic Rebalancing. World Economic and Financial Surveys, International Monetary Fund, April

International Monetary Fund (2012). World Economic Outlook. World Economic and Financial Surveys, International Monetary Fund, April

Iskandar, C.L, dan Yanfitri (2011). Keterkaitan Perdagangan AS-EU dengan negara Lainnya: Potensi Spill-over Krisis di negara Maju. Catatan Riset No.13/16/DKM/BRE/CR, Biro Riset Ekonomi, Direktorat Riset Ekonomi dan Kebijakan Moneter, Bank Indonesia.

Mori, Tomoko dan Hitoshi Sasaki (2007). Interpendence of Production and Incomein Asia Pasific Economies : An International Input Output Approach. Bank of Japan Working Paper Series No. 07-E-26.

Mun-Heng TOH (1998). Projecting the Leontief inverse directly by the RAS method. Paper prepared for presentation at the 12th International Conference on Input-Output Techniques, New York, 18-22 May 1998

Pula Gabor dan Tuomas A Peltonen (2009). Has Emerging Asia Decoupled? An Analysis of Production and Trade Linkages Using The Asian International Input Output Table. Working Paper Series No. 993 European Central Bank. 
LAMPIRAN 1. TABEL ASIAN INTERNATIONAL INPUT OUTPUT (AIO)

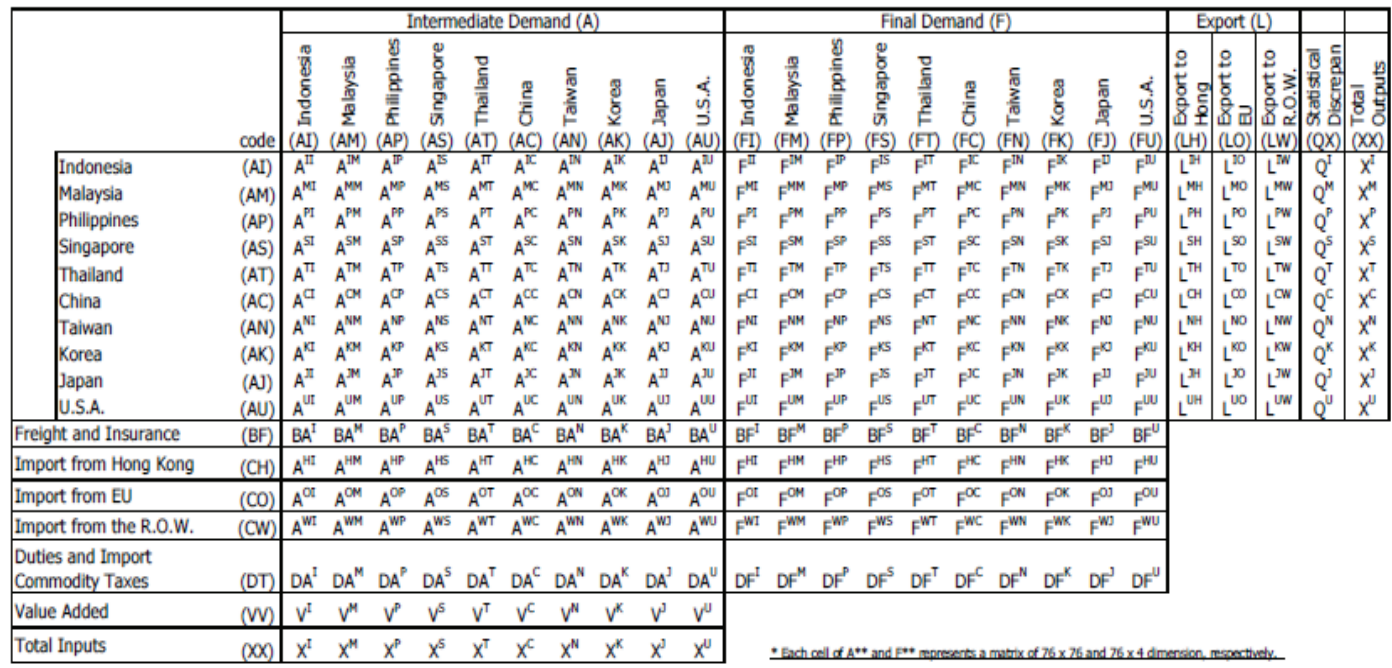

Sumber: Pula Gabor dan Tuomas A Peltonen (2009). Has Emerging Asia Decoupled? An Analysis of Production and Trade Linkages Using The Asian International Input Output Table. Working Paper Series No. 993 European Central Bank.

LAMPIRAN 2. UPDATING TABEL AIO

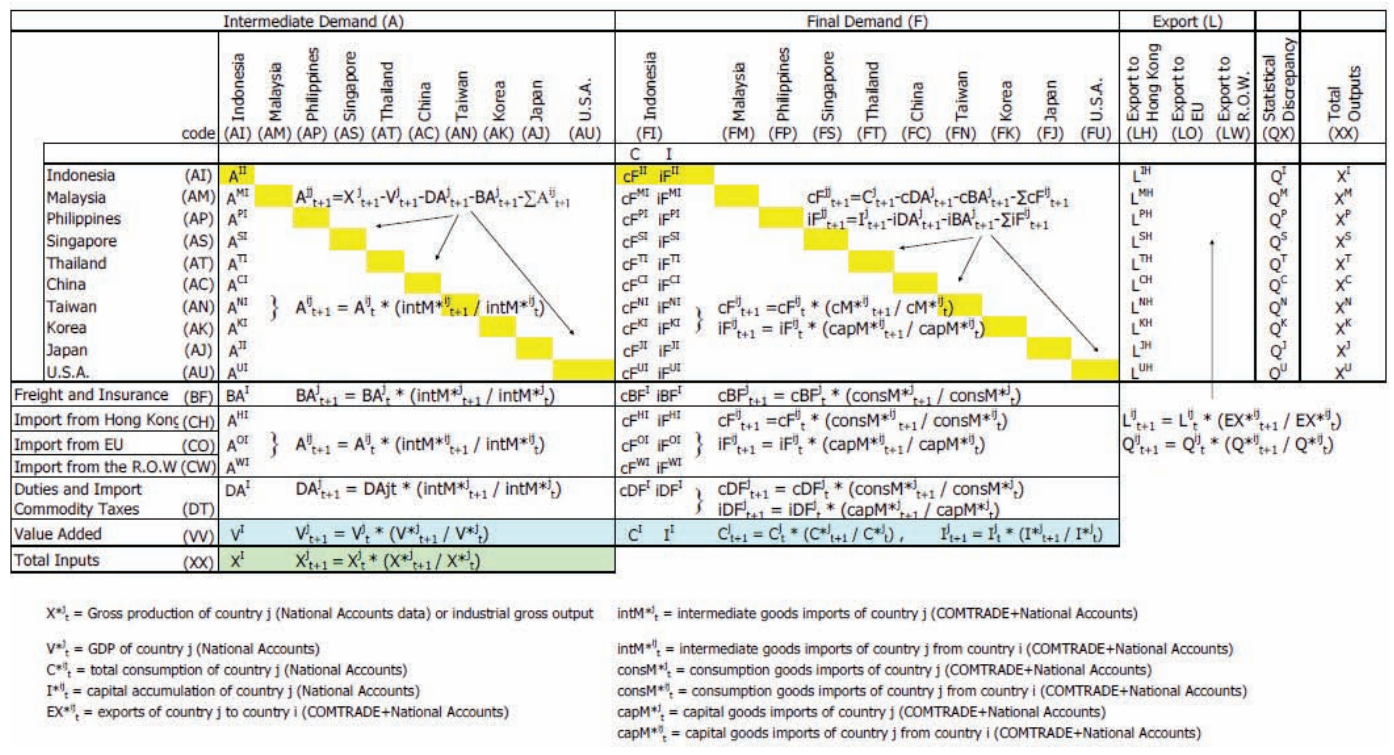

Sumber: Pula Gabor dan Tuomas A Peltonen (2009). Has Emerging Asia Decoupled? An Analysis of Production and Trade Linkages Using The Asian International Input Output Table. Working Paper Series No. 993 European Central Bank. 


\section{LAMPIRAN 3.TABEL KONVERSI, AIO 24 SEKTOR}

\begin{tabular}{|c|c|c|c|c|c|c|c|}
\hline \multicolumn{2}{|r|}{7 Sector Classification } & \multicolumn{2}{|r|}{24 Sector Classification } & \multicolumn{2}{|r|}{76 Sector Classification } & \multicolumn{2}{|r|}{78 Sector Classification (1995) } \\
\hline \multirow[t]{2}{*}{ Code } & $\begin{array}{ll}\text { Description } \\
\end{array}$ & Code & $\begin{array}{c}\text { Description } \\
\end{array}$ & Code & Description & Code & $\begin{array}{c}\text { Description } \\
\end{array}$ \\
\hline & & & & \multirow{2}{*}{\multicolumn{4}{|c|}{$\begin{array}{l}\text { TNIERMEDIATE SECTORS } \\
001 \text { Paddy }\end{array}$}} \\
\hline \multirow[t]{12}{*}{001} & \multirow{12}{*}{$\begin{array}{l}\text { Agric ulture, } \\
\text { livestock, } \\
\text { forestry } \\
\text { and fishery }\end{array}$} & 001 & Padds & & Paddy & 001 & Paddy \\
\hline & & \multirow[t]{8}{*}{002} & \multirow[t]{8}{*}{ Other agric ultural products } & 002 & Other grain & $007 \mathrm{~A}$ & Other grain \\
\hline & & & & \multirow[t]{4}{*}{003} & \multirow[t]{4}{*}{ Foodcrops } & 002 & Cassava \\
\hline & & & & & & 004 & Sugar cane and beet \\
\hline & & & & & & 005 & Oil parm and coc onuts \\
\hline & & & & & & $007 \mathrm{~B}$ & Other foodcrops \\
\hline & & & & \multirow[t]{3}{*}{004} & \multirow[t]{3}{*}{ Non-foodcrops } & 003 & Natural rubber \\
\hline & & & & & & 006 & Fiber crops \\
\hline & & & & & & 008 & Other commercial crops \\
\hline & & 003 & Livestock and poultry & 005 & Livestock and poultry & 009 & Livestock and poultry \\
\hline & & 004 & Forestry & 1006 & Forestry & 010 & Forestry \\
\hline & & 005 & Fishery & 007 & Fishery & 011 & Fishery \\
\hline \multirow[t]{6}{*}{002} & \multirow{6}{*}{$\begin{array}{l}\text { Mining and } \\
\text { quarrying }\end{array}$} & \multirow{6}{*}{006} & Crude petroleum and natural gas & 008 & Crude petroleum and natural gas & 012 & Crude petroleum and natural gas \\
\hline & & & \multirow{5}{*}{ Other mining } & 009 & Iron ore & $1015 \mathrm{~A}$ & Iron ore \\
\hline & & & & \multirow[t]{3}{*}{010} & \multirow[t]{3}{*}{ Other metallic ore } & 013 & Copper ore \\
\hline & & & & & & $\overline{014}$ & Tin ore \\
\hline & & & & & & 015B & Other metallic ore \\
\hline & & & & 011 & Non-metallic ore and quarrying & 016 & Non-metallic ore and quarrying \\
\hline \multirow[t]{9}{*}{003} & \multirow[t]{9}{*}{ Manufacturing } & \multirow[t]{9}{*}{008} & \multirow[t]{9}{*}{ Food, beverage and tobacco } & \multirow[t]{2}{*}{012} & \multirow[t]{2}{*}{ Milled grain and flour } & 018 & Milled rice \\
\hline & & & & & & 019 & Other milled grain and flour \\
\hline & & & & 013 & Fish products & $021 \mathrm{~A}$ & Fish products \\
\hline & & & & 014 & Slaughte ing, meat products and dairy products & $021 \mathrm{~B}$ & Slaughtering and meat products \\
\hline & & & & \multirow[t]{3}{*}{015} & \multirow[t]{3}{*}{ Other food products } & 017 & OIl and fats \\
\hline & & & & & & 020 & Sugir \\
\hline & & & & & & $021 \mathrm{C}$ & Other food products \\
\hline & & & & 016 & Beverage & $022 \mathrm{~A}$ & Beverage \\
\hline & & & & 017 & Tobacco & $022 \mathrm{~B}$ & Tobacco \\
\hline
\end{tabular}

TABEL KONVERSI, AIO 24 SEKTOR (Cont.)

\begin{tabular}{|c|c|c|c|c|c|}
\hline \multirow[t]{6}{*}{009} & \multirow{6}{*}{ Textile, leather, and the products thereof } & 018 & Spinning & 023 & Spinning \\
\hline & & 019 & Weaving and dreing & 1024 & Wearing and dyeing \\
\hline & & 020 & Knitting & 025 & Knitting \\
\hline & & 021 & Wearing apparel & 026 & Wearing apparel \\
\hline & & 022 & Other made-up textle products & 027 & Other made-up textle products \\
\hline & & 023 & Leather and leather products & 028 & Leather and leather products \\
\hline \multirow[t]{3}{*}{010} & \multirow[t]{3}{*}{ Timber and wooden produxts } & 024 & Timber & 029 & Timber \\
\hline & & 025 & Wooden furriture & $030 \mathrm{~A}$ & Furniture \\
\hline & & 026 & Other wooden products & O30B & Other wooden products \\
\hline \multirow[t]{2}{*}{011} & \multirow[t]{2}{*}{ Pulp, paper and printing } & 027 & \begin{tabular}{|l|l|} 
Pulp and paper \\
\end{tabular} & 031 & \begin{tabular}{|l|l|} 
Pulp and paper \\
\end{tabular} \\
\hline & & 028 & Printing and publishing & 032 & Printing and publishing \\
\hline \multirow[t]{5}{*}{012} & \multirow[t]{5}{*}{ Chemical products } & 029 & Srnthe tic resins and fiber & $033 \mathrm{~A}$ & Synthe ic resins and fiber \\
\hline & & 030 & Basic industrial chemic als & $033 \mathrm{~B}$ & Other basic industrial chemic als \\
\hline & & 031 & Chemical fertihzers and pesticides & 034 & Chemical fertilizers and pesticides \\
\hline & & $\overline{032}$ & Drugs and medicine & $035 \mathrm{~A}$ & Drugs and medicine \\
\hline & & 033 & Other chemical products & 1035B & Other chemical products \\
\hline 013 & Petroleum and petro products & 034 & Refined petroleum and its products & 036 & Refined petroleum andits products \\
\hline 019 & Other manufacturing products & 035 & Plastic products & $1050 \mathrm{~A}$ & Plastic products \\
\hline \multirow[t]{2}{*}{014} & \multirow{2}{*}{ 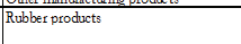 } & 1036 & Tires and tubes & 037 & Tires and tubes \\
\hline & & 037 & Other rubber products & 038 & Other rubber products \\
\hline \multirow[t]{3}{*}{015} & \multirow[t]{3}{*}{ Non-metallic mineral products } & 038 & Cement and cement products & 039 & Cement and cement products \\
\hline & & 039 & Glass and glass products & 040 & Glass and glass products \\
\hline & & 040 & Other non-metallic mineral products & 041 & Other non-metallic mineral products \\
\hline \multirow[t]{3}{*}{016} & \multirow[t]{3}{*}{ Metal products } & 041 & Iron and steel & 042 & Iron and steel \\
\hline & & 042 & Non-ferrous metal & 043 & Non-ferrous metal \\
\hline & & 043 & Metal products & 044 & Metal products \\
\hline \multirow[t]{11}{*}{017} & \multirow[t]{11}{*}{ Machinery } & 044 & Boilers, Engines and turbines & 045E & Engines and turbines \\
\hline & & 045 & General machinert & $045 \mathrm{C}-2$ & Ordinary industrial machinery \\
\hline & & 046 & Metal working machinery & 045B-1 & Specialized industrial machinery \\
\hline & & & & $045 \mathrm{C}-2$ & Ordinary industrial machinery \\
\hline & & $\overline{047}$ & Specialaized machinery & 045A & Agricultural machinery \\
\hline & & & & $045 \mathrm{~B}-2$ & Specialized industrial machinery \\
\hline & & 048 & Heavr Electrical equipment & $045 \mathrm{D}$ & Heart Electric machinert \\
\hline & & 049 & Television sets, radios, audios andcommunic ation equipment & $046 \mathrm{~A}$ & Electronic s and electronis products \\
\hline & & 050 & Eectronic computing equipment & & \\
\hline & & 051 & Semic onductors and integrated circ vits & & \\
\hline & & 052 & Other electronics and elec tronic produrts & & \\
\hline
\end{tabular}


TABEL KONVERSI, AIO 24 SEKTOR (Cont.)

\begin{tabular}{|c|c|c|c|c|c|c|c|}
\hline & & & & $\frac{053}{054}$ & $\begin{array}{l}\text { Household electric al equipment } \\
\text { Lighting fixtures, batteries, wining and others }\end{array}$ & $046 \mathrm{~B}$ & Other electric machinery and applianse \\
\hline & & 018 & Transport equipment & 055 & Motor vehicles & $047 \mathrm{~A}$ & Motor vehicles \\
\hline & & & & 056 & Motor creles & $047 \mathrm{~B}-1$ & Motor cycles and bicycles (Motor crcyles) \\
\hline & & & & 057 & Shipbulding & $048 \mathrm{~B}$ & Shipbuilding \\
\hline & & & & 058 & Other transport equipment & $047 \mathrm{~B}-2$ & Motor crycles and bicycles (Bicycles) \\
\hline & & & & & & $048 \mathrm{~A}$ & Aircrafts \\
\hline & & & & & & $048 \mathrm{C}$ & Other transport equipment \\
\hline & & 019 & Other manufact turing products & 059 & Precision machines & 049 & \begin{tabular}{|l|} 
Precision machines \\
\end{tabular} \\
\hline & & & & 060 & Other manufact turing products & 050B & Other ma nufacturing products \\
\hline 004 & Elec tricity, gqs & 020 & Electricity, gas, and water supply & 061 & Electricity and gas & 051 & Electricity, gas and water supply \\
\hline 005 & $\begin{array}{l}\text { and water sugply } \\
\text { Construction }\end{array}$ & 021 & Construction & $\frac{102}{1063}$ & \begin{tabular}{|l|} 
Water supplv \\
Building construction
\end{tabular} & $052 \mathrm{~A}$ & Building construction \\
\hline & & & & 064 & Other construc tion & $052 \mathrm{~B}$ & Otherconstruction \\
\hline 006 & Trade and transport & 022 & Trade and transport & 065 & Wholesale and retail trade & $053 \mathrm{~A}$ & Whole sale and retril trade \\
\hline & & & & 066 & Transportation & $05 \hat{\jmath} \mathrm{B}$ & Transportation \\
\hline 007 & Services & 023 & Services & 067 & Telephone and telecommunication & $054 \mathrm{~A}$ & Telephone and telecommunic ation \\
\hline & & & & 068 & Finance and insurance & $054 \mathrm{~B}$ & Finance and insurance \\
\hline & & & & 069 & Real estate & 054D-1 & Other services \\
\hline & & & & 070 & Education and research & $054 \mathrm{C}$ & Eduxation and research \\
\hline & & & & 071 & Medical and health serrice & $054 \mathrm{D}-2$ & \begin{tabular}{|l|} 
Other services \\
\end{tabular} \\
\hline & & & & 072 & Restraunts & 054D-3 & Other services \\
\hline & & & & 073 & Hotel & $054 \mathrm{D}-4$ & Other services \\
\hline & & & & 074 & Other services & 054D-5 & Other services \\
\hline & & & & 076 & \begin{tabular}{|l|} 
Unclassified \\
\end{tabular} & 056 & Unclassified \\
\hline & & 024 & Public administration & 1075 & Public administration & 055 & Public administration \\
\hline & & & FINAL DEMAND SECTORS & & & & \\
\hline 001 & Private consumption & 001 & Private consumption & 001 & Private consumption & 001 & Private consumption \\
\hline 002 & Governemtn consumption & 002 & Governemtn consumption & 002 & Governemm consumption & 002 & Gorememtn consumption \\
\hline 003 & Gross fixedcapital formation & 003 & Gross fixed capital formation & 003 & Gross fixed capital formation & 003 & Gross fised capital formation \\
\hline 004 & Changes in stocks & 1004 & Changes in stocks & 1004 & Changes in stocks & 004 & Changes in stocks \\
\hline & & & VALUE ADDED SECTORS & & & & \\
\hline 001 & Wages and salary & 001 & Wages and salary & 001 & Wages and salary & 001 & Wages and salary \\
\hline 002 & Operating surplus & 002 & Operating surplus & 002 & Operating surplus & 002 & Operating surplus \\
\hline 003 & Depreciation & 003 & Depreciation & 1003 & Depreciation & 003 & Depreciation \\
\hline 004 & Indirect taxes less subsidies & 1004 & Indirect taxes less subsides & 1004 & Indirect taxes less subsidies & 004 & Indirect taxes less subsidies \\
\hline
\end{tabular}


372 Buletin Ekonomi Moneter dan Perbankan, Volume 16, Nomor 4, April 2014

Halaman ini sengaja dikosongkan 